\title{
Organized Section Update
}

$\mathrm{T}$ he organized sections unite APSA members who share common interests, providing networks to organize meetings and coordinate communications under association auspices. Also, sections offer outlets for research and opportunities for scholarship. They have become a vital part of the association by sponsoring panels at the Annual Meeting, producing informative newsletters, and recognizing the scholarly achievements of their members. Listed in the following pages is the update for the Organized Sections 2018-19. For recent changes or corrections to this update and for contact information, visit www.apsanet.org.

\section{SECTION 1: FEDERALISM \& INTERGOVERNMENTAL RELATIONS}

Formed: 1983 / Dues: \$0 for students and \$25 for all other members

The purpose of this section is to plan, develop, and implement professional activities for association members with interests in federalism, intergovernmental relations, and state and local government.

Website: http://www.apsanet.org/section1

Chair: Andrew Karch, University of Minnesota

Secretary: Michael Hail, Morehead State University

Treasurer: Michael Hail, Morehead State University

Editor: Publius: The Journal of Federalism: John Dinan, Wake Forest University

2019 Annual Meeting Program Chair: Jacqueline Chattopadhyay, University of North Carolina at Charlotte

Executive Council: Paul Manna, College of William and Mary; Jennifer Wolak, University of Colorado; David Robertson, University of Missouri at St. Louis; Mona Vakilifathi, New York University; Paul Nolette, Marquette University; Srinivas Paronandi, University of Colorado; Carol Weissert, Florida State University; Maria Escobar-Lemmon; Texas A\&M University; Philip Rocco, Marquette University

Martha Derthick Best Book Award

Conferred for the best book on federalism and intergovernmental relations published at least 10 years ago that has made a lasting contribution to the study of federalism and intergovernmental relations.

Nominations due: March 1, 2019

Award Committee: Carol Weissert, Chair, Florida State University; Paul Manna, College of William and Mary; Adam Myers, Providence College

Deil S. Wright Best Paper Award

Conferred for the best paper in the field of federalism and intergovernmental relations presented at the previous year's APSA Annual Meeting.

Nominations due: December 1, 2018

Award Committee: Srinivas Parinandi, Chair, University of Colorado; Claudia Avellaneda, Indiana University; Philip Rocco, Marquette University

\section{LIST OF ORGANIZED SECTIONS (WITH NUMBER)}

African Politics Conference Group (44)

American Political Thought (47)

Canadian Politics (40)

Class and Inequality (45)

Comparative Democratization (35)

Comparative Politics (20)

Conflict Processes (7)

Elections, Public Opinion, and Voting Behavior (32)

European Politics and Society (21)

Experimental Research (42)

Federalism \& Intergovernmental Relations (1)

Foreign Policy (31)

Foundations of Political Theory (17)

Health Politics and Policy (39)

Human Rights (36)

Ideas, Knowledge and Politics (46)

Information Technology and Politics (18)

International Collaboration (48)

International History and Politics (34)

International Security (19)

Law and Courts (2)

Legislative Studies (3)

Middle East and North Africa Politics (49)

Migration and Citizenship (43)

New Political Science (27)

Political Communication (23)

Political Economy (25)

Political Methodology (10)

Political Networks (41)

Political Organizations and Parties (5)

Political Psychology (28)

Political Science Education (29)

Politics and History (24)

Politics, Literature, and Film (30)

Presidents and Executive Politics (9)

Public Administration (6)

Public Policy (4)

Qualitative and Multi-Method Research (37)

Race, Ethnicity and Politics (33)

Religion and Politics (11)

Representation and Electoral Systems (8)

Science, Technology \& Environmental Politics (15)

Sexuality and Politics (38)

State Politics and Policy (22)

Urban and Local Politics (13)

Women and Politics Research (16) 
Daniel Elazar Distinguished Scholar Award

Recognizes distinguished scholarly contributions to the study of federalism and intergovernmental relations.

Nominations due: March 1, 2019

Award Committee: Paul Nolette, Marquette University; Laura Evans, University of Washington; Henry Hale, George Washington University

John Kincaid Award

Conferred on the author(s) of the best article published in Publius: The Journal of Federalism in the previous year.

Nominations due: March 1, 2019

Award Committee: Mona Vakilifathi, Chair, New York University; David Siroky, Arizona State University; Jennifer Wolak, University of Colorado

\section{SECTION 2: LAW AND COURTS}

Formed: 1983 / Dues: \$25 for student members and \$30 for all other members

The purpose of this section is to promote interest in teaching and research in the areas of law and the judicial process.

Website: http://www.lawcourts.org

Chair: Julie Novkov, University at Albany, SUNY

Chair-Elect: Kirk Randazzo, University of South Carolina

Secretary: Christina Boyd, University of Georgia

Treasurer: Lee Walker, University of North Texas

Editor: Journal of Law and Courts: Kevin McGuire, University of North Carolina at Chapel Hill

Editor: Law and Courts Newsletter: Todd Collins, Western Carolina University

2019 Annual Meeting Program Chairs: Joe Ura, Texas A\&M University; Pamela Corley, Southern Methodist University

Executive Council: Virginia Hettinger, University of Connecticut; Lydia Tiede, University of Houston; Nancy Scherer, Wellesley College; Bethany Blackstone, University of North Texas; Brandon Bartels, George Washington University

Best Graduate Student Paper Award

This award (formerly the CQ Press Award) is given annually for the best paper in the field of law and courts written by a graduate student. To be eligible, the nominated paper must have been written by a full-time graduate student. Single- and coauthored papers are eligible. In the case of coauthored papers, each author must have been a full-time graduate student at the time the paper was written. Submitted papers may have been written for any purpose (including papers written for seminar, scholarly meetings, and for potential publication in academic journals). This is not, however, a dissertation or thesis prize. Papers may be nominated by faculty members or by the students themselves. The papers must have been written during the 12 months previous to the nomination deadline.

Nominations due: TBA

Award Committee: TBA

Teaching and Mentoring Award
The Teaching and Mentoring Award recognizes innovative teaching and instructional methods and materials in law and courts. Examples of innovations that might be recognized by this award include (but are not limited to) outstanding textbooks, websites, classroom exercises, syllabi, or other devices designed to enhance the transmission of knowledge about law and courts to undergraduate or graduate students. Any member of the section may make a nomination for the Teaching and Mentoring Award by submitting a statement identifying the nominee and outlining the nature of the her or his innovation and the contribution it makes to achieving the purposes of the award (email attachments, in the form of .pdf files, are acceptable). The Teaching and Mentoring Award is supported by a generous contribution from the Division for Public Education of the American Bar Association.

\section{Nominations due: TBA}

\section{Award Committee: TBA}

\section{Law and Courts Service Award}

The Law and Courts Service Award recognizes service to the section in the literal sense, as in service on committees and in leadership positions, as well as service within the section, as in service to the profession within the field of law and courts in the form of archiving data, promoting infrastructure, representing the profession in the media, etc.

Nominations due: TBA

\section{Award Committee: TBA}

\section{Best Conference Paper Award}

The Law and Courts Best Conference Paper Award (formerly the American Judicature Society Award) is given annually for the best paper on law and courts presented at the previous year's annual meetings of the American, International, or regional political science associations. Single- and coauthored papers, written by political scientists, are eligible. Papers may be nominated by any member of the section.

Nominations due: TBA

\section{Award Committee: TBA}

\section{Best Journal Article Award}

This award recognizes the best journal article in the field of law and courts written by a political scientist and published during the previous calendar year. Articles published in all refereed journals and in law reviews are eligible, but book reviews, review essays, and chapters published in edited volumes are not eligible. Journal editors and members of the section may nominate articles.

\section{Nominations due: TBA}

\section{Award Committee: TBA}

\section{Herman Pritchett Award for Best Book}

The C. Herman Pritchett award is given annually for the best book on law and courts written by a political scientist and published the previous year. Please note that case books and edited books are not eligible for consideration. Books may be nominated by publishers or by members of the section.

Nominations due: TBA

\section{Award Committee: TBA}

Law and Courts Lasting Contribution Award

Awarded annually to a book or journal article, 10 years old or 
older, that has made a lasting impression on the field of law and courts. Only books and articles written by political scientists are eligible; single-authored works produced by winners of the Lifetime Achievement Award are not eligible. Any member of the section may submit a nomination. The nomination should include a statement outlining the nature of the contribution of the nominated work.

\section{Nominations due: TBA}

\section{Award Committee: TBA}

\section{Law and Courts Lifetime Achievement Award}

Given for a lifetime of significant scholarship, teaching, and service to the Law and Courts field. Nominees must be political scientists who are at least 65 years of age or who have been active in the field for at least 25 years. Nominations from previous competitions will be carried forward to the current year's competition. The committee will retain nominations for three years, but you are invited to re-nominate an individual and renew the materials in the file during each cycle. Nominations may be made by any member of the section and should consist of a statement outlining the contributions of the nominee and, if possible, a copy of the nominee's curriculum vitae. Nominations should be submitted to the chair of the selection committee.

\section{Nominations due: TBA}

\section{Award Committee: TBA}

\section{SECTION 3: LEGISLATIVE STUDIES}

Formed: 1983 / Dues: \$33 for professional members for both hard copy and electronic access to LSQ; $\$ 23$ for professional members with electronic-only access to LSQ; \$3 for student members with electronic-only access to LSQ

The purpose of this section is to provide members with an interest in legislative processes, behavior, and representation opportunities to meet and exchange ideas.

Website: http://www.legislativestudies.org

Chair: Wendy J. Schiller, Brown University

Secretary: James Curry, University of Utah

Treasurer: James Curry, University of Utah

Editor: Legislative Studies Quarterly: Brian Crisp, Washington University in St. Louis

2019 Annual Meeting Program Chairs: Eleanor Powell, University of Wisconsin-Madison; Gisela Sin, University of Illinois

Executive Council: Leslie Schwindt-Bayer, Rice University; Sebastian Saiegh, University of California at San Diego; Jonathan Slapin, University of Essex; Michael Rocca, University of New Mexico

\section{Alan Rosenthal Prize}

In the spirit of Alan Rosenthal's work, this prize is dedicated to encouraging young scholars to study questions that are of importance to legislators and legislative staff and to conduct research that has the potential application to strengthening the practice of representative democracy. Topics may be national or subnational in focus and apply to any country. Preference will be given to comparative legislative research among legislatures in the same country or across countries. The prize is funded by the Trust for Representative Democracy of the National Conference of State Legislature and the State Legislative Leaders Foundation. The book or article must be published in the previous calendar year and authored by scholars below the rank of associate professor or legislative practitioners at the equivalent career stage. In the case of books or articles by multiple authors, the work is eligible for the award if at least one author is below the rank of associate professor. Nominations for award may be done by anyone, including authors, publishers, departments, or practitioners. Please send a cover letter and a copy of the work to each member of prize committee.

Nominations Due: March 1, 2019

Award Committee: Ruth Bloch Rubin, University of Chicago; Domingo Morel, University of Rutgers - Newark; Charles Shipan, University of Michigan

\section{Carl Albert Dissertation Award}

The Carl Albert Dissertation Award is given annually for the best dissertation in legislative studies. Topics may be national or subnational in focus-on Congress, parliaments, state legislatures, or other representative bodies. The prize is funded by the Carl Albert Congressional Research and Studies Center at the University of Oklahoma. In addition to the cash prize associated with the award, winners are typically invited to guest lecture on the OU campus with travel expenses paid by the Carl Albert Center. Dissertations must have a copyright date of one or two years previous to the year in which the award is presented. Terms for submitting dissertation: (1) one copy sent to each member of the committee; (2) no more than one submission per PhD-granting department; (3) letter form the department indicating the selection; and (4) a letter from the dissertation chair, or other appropriate committee member, describing the significance of the work.

Nominations Due: March 1, 2019

Award Committee: Alison W. Craig, Chair, University of Texas at Austin; Melinda Ritchie, University of California at Riverside; Wendy Schiller, Brown University

\section{CQ Press Award}

For the best paper on legislative studies presented at the previous year's APSA Annual Meeting.

Nominations Due: March 1, 2019

Award Committee: Olle Folke, Co-Chair, Uppsala University; Johanna Rickne, Co-Chair; Stockholm University; Emily Schilling, University of Tennessee at Knoxville

\section{Jewell-Loewenberg Paper Award}

The Jewell-Loewenberg Paper Award for the best article in Legislative Studies Quarterly in the previous year. All articles published in $L S Q$ in the previous year are under consideration.

Nominations Due: March 1, 2019

Award Committee: Sarah Anzia, Co-Chair, University of California at Berkeley; Terry Moe, Co-Chair; Stanford University; Jennifer Garcia, Oberlin College

\section{Richard F. Fenno, Jr. Prize}

The Richard F. Fenno, Jr. Prize is awarded to the best book in legislative studies published in the previous year. In the tradition of Professor Fenno's work, this prize is designed to honor work that is both theoretically and empirically strong. Moreover, this prize is dedicated to encouraging scholars to pursue new and different avenues of research in order to find answers to previously unexplored questions about the nature of politics. Nominations 
must have a copyright date of the year prior to that in which the award is given, and a copy of the book must be sent to each member of the committee.

\section{Nominations Due: March 1, 2019}

Award Committee: Sarah Binder, Chair, George Washington University; David Parker, University of Montana; Michael Minta, University of Minnesota

\section{Barbara Sinclair Legacy Award}

The Barbara Sinclair Legacy Award is designed to honor the work of a scholar or set of scholars who have contributed a lifetime of significant scholarship to the study of legislative politics. In the tradition of Professor Sinclair's body of work, recipients of this award will have focused on individual legislative behavior, institutional rules, or the role of party in shaping legislative politics. This award is also intended to recognize scholars who employ a range of methods in their research. Nominations can be made by any member of the section.

Nominations Due: March 1, 2019

Award Committee: Tracy Sulkin, Chair, University of Illinois; John Wilkerson, University of Washington; Nate Monroe, University of California at Merced

\section{Emerging Scholar Award}

The Emerging Scholar award is designed to recognize a scholar who is no more than six years from the year of their PhD who has informed the study of legislative politics through innovative and rigorous scholarship. The recipient of this award will be an individual who has a strong early career publication trajectory, and has presented their work actively at conferences and other public venues. Letters of nomination for this award should be sent to the committee along with the candidate's most recent $\mathrm{CV}$.

Nominations Due: March 1, 2019

Award Committee: Tiffany Barnes, Co-Chair, University of Kentucky; Justin Kirkland, Co-Chair, University of Virginia; Christian Grose, University of Southern California

\section{SECTION 4: PUBLIC POLICY}

Formed: 1983 / Dues: \$15 for students and professional members

The Organized Section on Public Policy is committed to producing rigorous empirical and theoretical knowledge of the processes and products of governing and the application of that knowledge to critical policy issues.

Website: https://connect.apsanet.org/s4/

Chair: Sarah Anzia, University of California, Berkeley

Chair Elect: Christopher Howard, The College of William \& Mary

Secretary: Edward Miller, University of Massachusetts, Boston

Treasurer: Edward Miller, University of Massachusetts, Boston

Editor: Policy Studies Journal: Edella Schlager, University of Arizona

2019 Annual Meeting Program Chair: Christopher Howard, The College of William \& Mary

Executive Council: Daniel Gillion, University of Pennsylvania; Lina Newton, CUNY Hunter College; Tim LaPira, James Madison University; Alexandra Filindra, University of Illinois, Chicago; Kristin Goss, Duke University; Joe Soss, University of Minnesota;
Dara Strolovitch, Princeton University; Rick Valelly, Swarthmore College; Daniel Galvin, Northwestern University; Jamila Michener, Cornell University; Jane Gingrich, University of Oxford; Alex Hertel-Fernandez, Columbia University

\section{Aaron Wildavsky Enduring Contribution Award}

The Aaron Wildavsky Enduring Contribution Award is given for the best book or article published in the general area of public policy during the past 20 plus years. The book or article should have had a major impact on the field. This award carries a prize of $\$ 500$.

Nominations deadline: March 15, 2019

Award Committee: Jeff Milyo, Chair, University of Missouri; Leah Stokes, University of California, Santa Barbara; Jonathan Mummolo, Princeton University

\section{Best Paper on Public Policy Award}

The Best Paper on Public Policy Award recognizes the best paper on Public Policy given at the previous APSA Annual Meeting. This award carries a $\$ 500$ prize.

Nominations deadline: March 15, 2019

Award Committee: Chris Witko, Chair, Pennsylvania State University; Tabitha Bonilla, Northwestern University; Clare Brock, Texas Woman's University

\section{Best Poster on Public Policy}

The Best Poster on Public Policy Award is given for the best paper or poster presented at the poster session at the previous APSA Annual Meeting. This award carries a prize of $\$ 500$.

Nominations deadline: March 15, 2019

Award Committee: Brenda Bushouse, Chair, University of Massachusetts; Kenneth Lowande, University of Michigan; Delphia Shanks-Booth, Hendrix College

\section{Best Comparative Policy Paper Award}

The Best Comparative Policy Paper Award recognizes a paper presented at the APSA Annual Meeting which is of particular distinction in the area of comparative public policy. It is granted in collaboration with and sponsored by the International Comparative Policy Analysis Forum and the Journal of Comparative Policy Analysis. Following nomination or self-nomination the paper is reviewed by a joint APSA/JCPA adjudication committee. The winning author(s) are awarded the JCPA Best Comparative Paper Award. This award carries a prize of $\$ 500$. The author is invited to submit the paper for publication consideration in the JCPA.

Nominations due: March 15, 2019

Award Committee: Jane Gingrich, Chair, University of Oxford; Ling Zhu, University of Houston; Tiffany Barnes, University of Kentucky

Theodore J. Lowi Policy Studies Journal Best Article Award The Theodore J. Lowi Policy Studies Journal Best Article Award is given to recognize an article of particular distinction published at any time in Policy Studies Journal. This award carries a prize of $\$ 500$.

Nominations due: TBA

Award Committee: Candis Watts Smith, Chair, University of North Carolina; Amy McKay, University of Exeter; Mallory SoRelle, Lafayette University

Excellence in Mentoring Award

The Excellence in Mentoring Award has been established to 
recognize sustained efforts by a senior scholar to encourage and facilitate the career of emerging political scientists in the field of public policy. This award carries a $\$ 500$ prize.

Nominations Due: March 15, 2019

Award Committee: Jamila Michener, Chair, Cornell University; Rachel Augustine Potter, University of Virginia; Derek Epp, University of Texas, Austin

\section{SECTION 5: POLITICAL ORGANIZATIONS AND PARTIES}

Formed: 1983 / Dues: \$5 for students and \$15 for all other members

The Organized Section on Political Organizations and Parties works to further scholarship on American political parties, comparative political parties, and interest groups. We do this in a number of different ways. Through our meetings, workshops, newsletter, and website, we provide a means of interaction and communication for like-minded scholars. At our annual workshop at the Annual Meeting we work to train scholars in the use of various methods or databases, or to promote new research in a particular area. Our participation as a section allows us to be a voice for our members' interests within APSA. We also organize the panels in our subfields for the Annual Meeting. Finally, we recognize excellence in scholarship with our awards for best book, best article, best APSA paper, career achievement, and emerging scholar. We are governed by the volunteer efforts of our officers and board. We are eager to reach out in new directions so let us hear your ideas!

Website: https://connect.apsanet.org/s5/

Chair: Beth L. Leech, Rutgers University

Secretary: Hans Noel, Georgetown University

Treasurer: Katie Marchetti, Dickinson College

2019 Annual Meeting Program Chairs: Tim LaPira, James Madison University and Kristin Wylie, James Madison University

Executive Council: Bruce Larson, Gettysburg College; Ann-Kristin Kolln, Aarhus University; Michael J. Malbin, SUNY, University at Albany; Robin Kolodny, Temple University

Samuel Eldersveld Career Achievement Award

Recognizes a scholar whose lifetime professional work has made an outstanding contribution to the field.

Nominations due: TBA

Leon Epstein Outstanding Book Award

Recognizes a book published in the last two calendar years that made an outstanding contribution to research and scholarship on political organizations and parties.

Nominations due: TBA

POP Best APSA Paper Award

Recognizes the best paper delivered on a Political Organizations and Parties-sponsored panel at the preceding Annual Meeting.

Nominations due: TBA

\section{Jack Walker Award}

Recognizes an article published in the last two calendar years that makes an outstanding contribution to research and scholarship on political organizations and parties.

Nominations due: TBA

Emerging Scholars Award
Given to a scholar who has received his or her $\mathrm{PhD}$ within the last five years and whose career to date demonstrates unusual promise.

Nominations due: TBA

\section{SECTION 6: PUBLIC ADMINISTRATION}

Formed: 1983 / Dues: \$8 for students \& \$15 for professional members

The purpose of this section is to provide an arena in which individuals interested in public administration may exchange ideas, enhance their professional development, and act to ensure that activities of the APSA encompass their interests.

Website: https://apsanet.org/section6

Chair: Kelly LeRoux, University of Illinois-Chicago

Chair-Elect: Scott Robinson, University of Oklahoma

Treasurer: Gene Brewer, University of Georgia

2019 Annual Meeting Program Chair: Ling Zhu, University of Houston

Executive Council: Karen Mossberger, Arizona State University; Daniel Hawes, Kent State University; Julie Dolan, Macalester College; Jill Nicholson-Crotty, Indiana University; Jessica Terman, George Mason University; Angel Molina, Arizona State University; David Switzer, University of Missouri; Manny Teodoro, Texas A\&M University

Herbert Kaufman Award

The Herbert Kaufman Committee will select the best paper presented on a panel sponsored (or cosponsored) by the Public Administration section at the APSA Annual Meeting each year. The section will follow APSA's guidance on what constitutes a "presented paper"-papers that were uploaded to the APSA Annual Meeting website, or posted/presented in a virtual or alternative form are eligible for the Kaufman award.

Nominations due: March 1,2019

Award Committee: Amanda Girth, Chair, Ohio State University; Claudia Avellaneda, Indiana University; Nathan Favero, American University

\section{Herbert A. Simon Book Award}

The Herbert A. Simon Book Award is given for significant contributions to public administration scholarship. Books with publication dates of 2016, 2017, and 2018 are eligible for the 2019 award. The book's orientation may be qualitative, quantitative, empirical, interpretive, ethnographic, historical, archival, normative, or theoretical. However, textbooks, revised editions of previously published books, and edited volumes are not eligible.

Nominations due: March 1, 2019

Award Committee: Karen Mossberger, Chair, Arizona State University; Aaron Deslatte, Northern Illinois University; Jiaqi Liang, University of Illinois at Chicago

\section{Volcker Junior Scholar Research Grant}

The APSA Organized Section for Public Administration invites applications and research proposals from junior scholars researching public administration issues affecting governance in the United States and abroad. Proposals will be judged on their potential to shed new light on important public administration questions, their scholarly and methodological rigor, and their promise for advancing practice and theory development. Individual grants are not renewable. 
Nominations due: March 1, 2019

Award Committee: Bill Resh, Chair, University of Southern California; Cullen Merritt, Indiana University - Purdue University Indianapolis; Alisa Moldavanova, Wayne State University

Public Administration Best Article Award

The Best Article Award recognizes the best article published in Public Administration.

Nominations due: TBA

Award Committee: TBA

SECTION 7: CONFLICT PROCESSES

Formed: 1984 / Dues: \$8 for students and \$15 for all other members

The purpose of this section is to be a forum for the study of any forms of political conflict both within and between nation-states.

Website: https://apsanet.org/section7

Chair: Kyle Beardsley, Duke University

Treasurer: Katja Kleinberg, Binghamton University

2019 Annual Meeting Program Chairs: Ursula Daxecker, University of Amsterdam; Yonatan Lupu, George Washington University

Executive Council: Govinda Clayton, ETH Zurich; Molly Melin, Loyola University Chicago; Matthew Fuhrmann, Texas A\&M University; Emily Ritter, University of California, Merced

\section{Best Paper Award}

This award is given annually for the best paper written by one or more untenured scholars (graduate students, post-docs, or faculty) and presented as part of a conflict processes-sponsored panel or poster session at the previous annual meeting. Papers are eligible only if all authors are untenured at the time the paper is presented. Nominations must be made by a member of the Conflict Processes section; self-nominations are encouraged.

Nominations due: October 15, 2018

Award Committee: Emily Ritter, Chair, Vanderbilt University; Matt Fuhrmann, Texas A\&M University; Jessica Stanton, University of Minnesota

\section{Best Book Award}

Given every two years for the book making the most outstanding contributions to the study of any and all forms of political conflict, either within or between nation-states, published in the two calendar years prior to the year in which the award is given. Edited volumes and textbooks are not eligible for the award. Nominations must be made by a member of the Conflict Processes section; selfnominations are encouraged. Nominations should be submitted to the committee chair, and a copy of the book should be sent to each member of the award committee.

Nominations due: March 15, 2018

Award Committee: Scott Straus, Chair, University of WisconsinMadison; Sarah Croco, University of Maryland, College Park; Scott Wolford, University of Texas at Austin

\section{J. David Singer Data Innovation Award}

The J. David Singer Data Innovation Award is given for the best data contribution to the study of any and all forms of political conflict, either within or between nation-states. Nominations must be made by a member of the Conflict Processes section; selfnominatons are encouraged. This is a biennial award.

Nominations due: March 15, 2018

Award Committee: Molly Melin, Chair, Loyola University Chicago; Idean Salehyan, University of North Texas; Jun Koga Sudduth, University Strathclyde

Lifetime Achievement Award

The Lifetime Achievement award is given every other year in recognition of scholarly contributions that have fundamentally improved the study of conflict processes.

Nominations due: March 15, 2018

Award Committee: Govinda Clayton, Chair, ETH Zurich; Elizabeth Menninga, University of Iowa; Cullen Hendrix, Denver University

\section{SECTION 8: REPRESENTATION AND ELECTORAL SYSTEMS}

Formed: 1984 / Dues: \$0 for students and \$10 for all other members

The purpose of this section is to promote teaching and research in the areas of representation and electoral systems, and to encourage communication among persons interested in these fields within the association and with related disciplines.

Website: https://apsanet.org/section8

Chair: Melody E. Valdini, Portland State University

Treasurer: Amanda Driscoll, Florida State University

2019 Annual Meeting Program Chair: David Lublin, American University

Executive Council: Ko Maeda, University of North Texas; Sarah Shair-Rosenfield; Kristin Wylie, James Madison University; Jessica Trounstine, University of California, Merced; Zeynep SomerTopcu, University of Texas at Austin; Todd Donovan, Western Washington University

\section{George H. Hallett Award}

The George H. Hallett Award is for the best book, at least ten years old, that has made a lasting contribution to the literature on representation and electoral systems.

Nominations due: April 19, 2019

\section{Award Committee: TBA}

\section{Lawrence Longley Award}

The Lawrence Longley Award is for the best article on representation and electoral systems published in the previous year.

Nominations due: April 19, 2019

Award Committee: TBA

Leon Weaver Award

The Leon Weaver Award is for the best paper presented at a conference panel sponsored by the Representation and Electoral Systems Section.

Nominations due: April 19, 2019

Award Committee: TBA

\section{SECTION 9: PRESIDENTS AND EXECUTIVE POLITICS}

Formed: 1985 / Dues: \$0 for students and \$10 for all other members

Presidents \& Executive Politics (PEP) of APSA is the premier 
association of scholars devoted to the study of the presidency and executives (formerly known as the Presidency Research Group). To that end, it welcomes diverse theoretical perspectives, analytical techniques, and data sources as they contribute to the advancement of scholarship and teaching. It also invites the contributions and perspectives of other disciplines. PEP values the establishment and enhancement of non-partisan links between scholarship, the real world of presidential and executive politics, and public policy.

Website: https://connect.apsanet.org/s9/

Chair: Diane Heith, St. John's University

Vice Chair: Daniel Ponder, Drury University

Secretary/Treasurer: Meena Bose, Hofstra University

2019 Annual Meeting Program Chair: Adam Warber, Clemson University

Executive Council: William Howell, University of Chicago; Matthew Beckman, University of California, Irvine; Julia Azari, Marquette University; Dan Gillion, University of Pennsylvania; Magna Inacio, Universidade Federal de Minas Gerais; Scott Mainwaring, Harvard University; Rachel Potter, University of Virginia; Jon Rogowski, Harvard University; Lilly Goren, Caroll University; Shareece Thrower, Vanderbilt University; Christina Kinane, University of Michigan

The Richard E. Neustadt Best Book Award

The Richard E. Neustadt Award will be given for the best book on executive politics published in the previous calendar year. The Neustadt Committee will also consider nominations when submitted for a separate, typically less frequent, Richard E. Neustadt Award for the Best Reference Work on the Presidency and Executive Politics published in the previous calendar year.

Nominations due: February 1, 2019

Award Committee: Michelle Belco, Chair, University of Houston; Ignacia Arana, Carnegie-Mellon University; Austin Trantham, Jacksonville University; Craig Goodman, University of Houston, Victoria

The Founders Best Paper Award

The Founders Award honoring Lester Seligman will be given for the best paper on executive politics authored by a PhD-holding scholar at the previous year's APSA Annual Meeting. Nominations should be emailed to the committee members.

Nominations due: March 1, 2019

Award Committee: Brian Newman, Chair, Pepperdine University; Alissandra T. Stoyan, Kansas State University; Charles Lamb, University of Buffalo; Alexander Bolton, Emory University

Founders Best Graduate Student Paper Award

The Founders Award honoring Stephen Wayne will be given for the best paper on executive politics presented by a graduate student at either the preceding year's APSA Annual Meeting or at any of the regional meetings in 2017-2018. Nominations should be emailed to the committee members.

Nominations due: March 1, 2019

Award Committee: Randy Adkins, Chair, University of NabraskaOmaha; Shannon Bow O'Brien, University of Texas; Alison Howard, Dominican University of California; John Dearborn, Yale University
The Legacy Award

The Legacy Award will be given to a living author for a book, essay, or article, published at least 10 years prior to the award year that has made a continuing contribution to the intellectual development of the fields of presidency and executive politics. Letters of nominations should provide a rationale for the work receiving the award.

Nominations due: February 1, 2019

Award Committee: Lilly Goren, Chair, Carroll University; Michael Genovese, Loyola-Marymount University; Matthew EshbaughSoha, University of North Texas

\section{George C. Edwards III Dissertation Award}

The George C. Edwards III Dissertation Award is given for the best dissertation in presidency research completed and accepted during the previous two calendar years (January 1, 2017-December $31,2018)$. The recipient will receive a $\$ 250$ award.

Nominations due: February 1, 2019

Award Committee: Donna Hoffman, Chair, University of Northern Iowa; Zak Taylor, Georgia Tech; Yu Ouyang, Perdue University Northwest; Andrew Reeves, Washington University in St. Louis

\section{SECTION 10: POLITICAL METHODOLOGY}

Formed: 1986 / Dues: \$9 for students for online-only access to Political Analysis; \$14 for students for print and online access to Political Analysis; $\$ 29$ for all other members for online-only access to Political Analysis; $\$ 34$ for all other members for print and online access to Political Analysis

The purpose of this section is to provide members having interests in methodology, including research design, measurement, and statistics, opportunities to meet and exchange ideas.

Website: http://polmeth.org

Chair: Kosuke Imai, Princeton University

Vice Chair: Suzanna Linn, Penn State University

Treasurer: Luke Keele, Georgetown University

Editor: Political Analysis: Jeff Gill, American University

Editor: The Political Methodologist: Justin Esarey, Wake Forest University

2019 Annual Meeting Program Chair: Molly Roberts, University of California, San Diego

Executive Council: Rocio Titiunik, University of Michigan

Career Achievement Award

Honors an outstanding career of intellectual accomplishment and service to the profession in the field of political methodology.

Nominations due: May 3, 2019

Award Committee: Jonathan Katz, Chair, California Institute of Technology; Jeffrey Lewis, University of California, Los Angeles; John Londregan, Princeton University; Jonathan Nagler, New York University

\section{Emerging Scholar Award}

Honors a young researcher, within ten years of his or her degree, who is making notable contributions to the field of political methodology.

Nominations due: May 3, 2019 
Award Committee: Luke Keele, Chair, Georgetown University; Sunshine Hillygus, Duke University; Arthur Spirling, New York University; Jake Bowers, University of Illinois, Urbana-Champaign

\section{Harold F. Gosnell Prize}

Recognizes the best work of political methodology presented at a political science conference in the previous year.

Nominations due: May 3, 2019

Award Committee: Matthew Blackwell, Chair, Harvard University; Marc Ratkovic, Princeton University; Fredrik Savje, Yale University

John T. Williams Dissertation Prize

Recognizes the best dissertation proposal in the area of political methodology. Proposals using quantitative or qualitative methods are welcomed. Proposals should follow National Science Foundation format guidelines.

Nominations due: May 3, 2019

Award Committee: Xun Pang, Chair, Tsinghua University; Dean Knox, Princeton University; Yiqing Xu, University of California, San Diego

Society for Political Methodology Poster Award (Student Methods Poster)

Recognizes the best political methodology poster given at any political science conference in the preceding year.

Nominations due: May 3, 2019

Award Committee: Justin Esarey, Chair, Wake Forest University; Ines Levin, University of California, Irvine; Chris Lucas, Washington University in St. Louis

Society for Political Methodology Poster Award (Student Applications Poster)

Recognizes the best political methodology poster given at any political science conference in the preceding year.

Nominations due: May 3, 2019

Award Committee: Alex Tahk, Chair, University of WisconsinMadison, Mark Pickup, Simon Fraser University; Michelle Torres, Washington University in St. Louis

Society for Political Methodology Poster Award (Faculty Poster) Recognizes the best political methodology poster given at any political science conference in the preceding year.

Nominations due: May 3, 2019

Award Committee: Curt Signorino, Chair, University of Rochester; Dan Hopkins, University of Pennsylvania; Kim Twist, San Diego State University

\section{Statistical Software Award}

Recognizes statistical software that has made a significant contribution to the advancement of political analysis.

Nominations due: May 3, 2019

Award Committee: Adam Glynn, Chair, Emory University; Sarah Bouchat, Northwestern University; Dustin Tingley, Harvard University

Warren Miller Article Award

Given for the best article in Political Analysis.

Nominations due: May 3, 2019
Award Committee: Jens Hainmueller, Stanford University; Pablo Barbera, London School of Economics; Jennifer Pan, Stanford University; Jeff Gill, American University

\section{Political Analysis Outstanding Reviewer Award}

Recognizes individuals who have provided exemplary assistance to Political Analysis during the previous year. Outstanding reviewers are those who provide excellent, timely, and productive feedback for authors who have submitted manuscripts to Political Analysis. Outstanding reviewers are also those who frequently review for the journal, and who provide the editors with productive advice about the submissions they review.

Nominations due: May 3, 2019

\section{Award Committee: Jeff Gill, American University}

\section{Excellence in Mentoring Award}

Honors members of the Society for Political Methodology who have demonstrated an outstanding commitment to mentoring and advising graduate and/or undergraduate students-particularly those from underrepresented groups.

Nominations due: May 3, 2019

Award Committee: Jacob Montgomery, Chair, Washington University in St. Louis; Chad Hazlett, University of California, Los Angeles; Nahomi Ichino, University of Michigan

The Box-Steffensmeier and Garcia ICPSR Summer Program Scholarship

The Janet Box-Steffensmeier Scholarship is a waiver of program scholar fees to attend one or both of the ICPSR Summer Program's four-week sessions. The scholarship will be awarded to a maximum of three women graduate students in $\mathrm{PhD}$ programs.

The John A. Garcia Award is a waiver of program scholar fees to attend one or both of the ICPSR Summer Program's four-week sessions. The scholarship will be awarded to a maximum of three underrepresented graduate students in $\mathrm{PhD}$ programs.

Nominations due: May 3, 2019

Award Committee: Saundra Schneider, Michigan State University; Adrienne Hosek, University of California, Davis; Lee Walker, University of North Texas

\section{SECTION 11: RELIGION AND POLITICS}

Formed: 1986 / Dues: \$24 for regular members, print \& online access to Politics and Religion; \$14 for regular members, online-only access to Politics and Religion; \$0 for student members

The purpose of this section is to encourage the study of the interrelations between religion and politics, including the politics of religious pluralism; law, religion, and governance; faith, practice, and political behavior; and the politics of secularism, in the United States as well as in comparative, historical, and global perspective.

Website: http://connect.apsanet.org/s11/home/

Chair: TBA

\section{Chair-Elect: TBA}

Treasurer: TBA

Editors: Politics and Religion: Elizabeth Oldmixon, University of North Texas

2019 Annual Meeting Program Chair: Christopher Hale, University of Alabama 


\section{Executive Council: TBA}

\section{Hubert Morken Book Award}

The Hubert Morken Award is given for the best publication dealing with religion and politics published during the last two years.

Nominations due: TBA

\section{Award Committee: TBA}

\section{Aaron Wildavsky Dissertation Award}

The Religion and Politics Section invites nominations for the Aaron Wildavsky Dissertation Award. The committee will look for and evaluate the following qualities in the submissions: clearly defined, timely/relevant topic; solid and original theoretical grounding; rigorous/innovative methodology; significance/potential impact of the dissertation project.

\section{Nominations due: TBA}

\section{Award Committee: TBA}

\section{Ted Jelen Award}

This prize is awarded to the best article published in the section's journal Politics and Religion. The winner of the award is selected by the journal's editors.

\section{Nominations due: TBA}

\section{Award Committee: TBA}

\section{Weber Best Conference Paper Award}

The Best Paper Award recognizes the best paper dealing with religion and politics presented at the previous year's APSA Annual Meeting. The paper should address a timely and relevant topic, within the discipline and beyond, in a theoretically innovative and methodologically thorough manner. Please submit nominations to the chair of the committee.

\section{Nominations due: TBA}

\section{Award Committee: TBA}

\section{Kenneth D. Wald Best Graduate Student Paper Award}

The Kenneth D. Wald Best Graduate Student Paper Award will be given annually to a conference paper studying any aspect of religion and politics presented by a $\mathrm{PhD}$ student in political science. The conference can be affiliated with any of the US-based political science associations or a conference affiliated with another association, such as the Society for the Scientific Study of Religion, the American Academy of Religion, the Middle East Studies Association, or the International Studies Association, as long as the paper was written by a student or students enrolled in a graduate program in political science. Papers written with faculty will not be considered. Papers presented at poster sessions are welcome. The award will be announced and presented at the annual APSA Annual Meeting during the business meeting. The award committee is under no obligation to make an award if no submissions merit such recognition.

Nominations due: TBA

Award Committee: TBA

\section{SECTION 13: URBAN AND LOCAL POLITICS}

Formed: 1986 / Dues: \$28 for professional members, print and online journal access; $\$ 18$ for professional members, online-only journal access; $\$ 18$ for student members, print and online journal access; $\$ 10$ for student members, online-only journal access
The purpose of the section is to promote interest in teaching and research in urban and local politics and policy. The section seeks to encourage communication among individuals interested in urban and local politics and policy within the association and within related disciplines.

Website: http://connect.apsanet.org/groups/urban-and-localpolitics-section-13/

Chair: Laura Reese, Michigan State University

Chair-Elect: Jill Simone Gross, Hunter College, CUNY

Secretary/Treasurer: Timothy Weaver, University at Albany, SUNY

Editors: Urban Affairs Review: Peter Burns, Loyola University, New Orleans; Jared Carr, University of Illinois, Chicago; Annette Steinacker, Loyola University, Chicago; Antonio Tavares, Universidade de Minho

2019 Annual Meeting Program Chairs: Jessica Trounstine, University of California, Merced; Reuel Rogers, Northwestern University

Executive Council: Christopher Hawkins, University of Central Florida; Alisha Holland, Princeton University; Adrienne LeBas, American University; Eduardo Moncada, Barnard College; Antonio Tavares, University of Minho; Daniel J. Hopkins, University of Pennsylvania; Richardson Dilworth, Drexel University; Jamila Michener, Cornell University; J. Celeste Lay, Tulane University; Mirya Holman, Tulane University; Domingo Morel, Rutgers University, Newark; Arturo Vega, St. Mary's University at Albany

\section{Dennis Judd Best Book Award}

The Best Book Award recognizes the best book on urban politics published in the previous year. Hard copies of nominated books should be sent to each committee member.

Nominations due: March 1, 2019

\section{Award Committee: TBA}

\section{Best Dissertation Award}

The Best Dissertation Award is given annually for the best dissertation on urban politics accepted in the previous year. The award comes with a $\$ 250$ prize. Electronic or hard copies of dissertations completed and approved in 2018 should be sent to each committee member.

Nominations due: March 1, 2019

\section{Award Committee: TBA}

Byran Jackson Dissertation Research on Minority Politics Award The Byran Jackson Award recognizes the outstanding scholarship by a graduate student studying racial and ethnic politics in an urban setting. The award comes with a $\$ 500$ prize. Electronic or hard copies of approved dissertation proposals should be sent to each committee member.

Nominations due: March 1, 2019

\section{Award Committee: TBA}

\section{Best Paper Award}

Urban Affairs Review is sponsoring a \$250 award for the Best Paper in urban, local, or regional politics. The chairs of all Urban and Local Politics Section panels will be asked to nominate papers. Authors from any panel on the annual meeting program can also self- 
nominate their papers. The best paper will be selected by a panel of three scholars: one editor of Urban Affairs Review, one member of the UAR editorial board, and one member of the executive council of the Urban and Local Politics Section. Nominations and papers must be received by September 30 of each year. Papers as written at the time of the APSA Annual Meeting will be judged. The award will be announced on the APSA Urban and Local Politics Section website and the UAR website by December 15. Authors of the winning paper will also be invited to submit to the Urban Affairs Review for fast-track review and publication, noting it was the winner of the Best Paper Award. This will be an annual award. Awards may not be made every year, depending on the number and quality of submissions.

Nominations due: September 30, 2018

Award Committee: TBA

\section{Norton Long Career Achievement Award}

The Norton Long Career Achievement Award is presented annually to a scholar who has made distinguished contributions to the study of urban politics over the course of a career through scholarly publication, the mentoring of students, and public service. Nominations and two supporting letters should be submitted electronically to all committee members.

Nominations due: March 1, 2019

Award Committee: TBA

\section{Susan Clarke Young Scholars' Award}

The Susan Clarke Young Scholars' award recognizes scholars who completed their $\mathrm{PhD}$ within the last three years (or are ABDs) and submitted a paper proposal for the 2019 APSA Annual Meeting to the 2019 program chairs. Please send accepted proposals to the 2019 program chairs and indicate that you are eligible for the Susan Clarke Young Scholars' Award.

Nominations due: March 1, 2019

\section{Award Committee: TBA}

\section{Clarence Stone Scholar Award}

The Clarence Stone Scholar Award recognizes up to two young scholars who are making a significant contribution to the study of urban politics. The award is to be given to up to two post-PhD scholars who are in their career (pre-tenure, or recently advanced within the last three years).

Nominations due: March 1, 2019

Award Committee: TBA

\section{SECTION 15: SCIENCE, TECHNOLOGY AND ENVIRONMENTAL POLITICS}

Formed: 1986 / Dues: \$0 for students and \$10 for all other members

The purpose of this section is to stimulate fundamental inquiry on science, technology, and environmental issues as political phenomena.

Website: http://stepsection.wordpress.com

Chair: Deserai Crow, University of Colorado Denver

Secretary/ Treasurer: David Shafie, Chapman University

Editor: Review of Policy Research: Graeme Auld, Carleton University

2019 Annual Meeting Program Chair: Kristin O’Donovan, Wayne State University
Executive Council: Aseem Prakash, University of WashingtonSeattle; Anne Clunan, Naval Postgraduate School; Graeme Auld, Carleton University; Chris Koski, Reed College; Kirsten Rodine Hardy, Northeastern University; Endre Tvinnereim, University of Bergen; Saba Siddiki, Syracuse University

Don K. Price Award

The Don K. Price Award is given for the best book on science, technology, and politics published in the past three years.

Nominations due: March 1, 2019

Award Committee: Mark Buntaine, Chair, University of California, Santa Barbara; Eric Patashnik, Brown University; Anne Clunan, Naval Postgraduate School

\section{Lynton Keith Caldwell Prize}

The Lynton Keith Caldwell Prize is given for the best book on environmental politics and policy published in the past three years.

Nominations due: March 1, 2019

Award Committee: Leigh Raymond, Chair, Purdue University; Roger Karapin, Hunter College, CUNY; Saba Siddiki, Syracuse University

\section{Virginia M. Walsh Dissertation Award}

The Virginia Walsh Dissertation Award is named in honor of a young scholar who tragically passed away recently, is given for the best dissertations in the field of science, technology, and environmental politics.

Nominations due: March 1, 2019

Award Committee: Gregory Thaler, University of Georgia; David Shafie, Chair, Chapman University; Megan Ruxton, University of Northern Iowa

\section{Paul A. Sabatier Best Conference Paper Award}

The Paul A. Sabatier Best Conference Paper Award is given for the best paper on science, technology, and environmental politics presented at the previous year's APSA Annual Meeting.

Nominations due: March 1, 2019

Award Committee: Rob DeLeo, Chair, Bentley University; Gwen Arnold, University of California, Davis; Matt Nowin, College of Charleston

The Elinor Ostrom Career Achievement Award

The Elinor Ostrom Career Achievement Award is given to an individual in recognition of their lifetime contribution to the study of science, technology, and environmental politics. Nominees must be at least 15 years from completing their $\mathrm{PhD}$ degree to be eligible.

Nominations due: March 1, 2019

Award Committee: Chris Koski, Chair, Reed College; Tom Birkland, North Carolina State University; Sarah Anderson, University of California, Santa Barbara

\section{The Evan Ringquist Best Paper Award}

The Evan Ringquist Best Paper Award is given for the best paper published in a relevant journal in the last two years. Relevant journals include political science, public administration, public policy, interdisciplinary environmental science, and science and technology studies journals.

Nominations due: March 1, 2019

Award Committee: Jonas Meckling, University of California, 
Berkeley; Kirsten Rodine-Hardy, Chair, Northeastern University; Endre Tvinnereim, University of Bergen

The Emerging Young Scholars Award

The Emerging Young Scholar Award is given in recognition of a researcher, within ten years of their $\mathrm{PhD}$ degree, who is making notable contributions to the field of science, technology, and environmental politics.

Nominations due: March 1, 2019

Award Committee: Rachel Krause, University of Kansas; Tanya Heikkila, University of Colorado Denver; Aseem Prakash, Chair, University of Washington

The STEP APSA Inclusion Travel Award

The STEP APSA Inclusion Travel Award will be granted to graduate students from underrepresented groups in the discipline who are accepted to present a paper at the APSA Annual Meeting. They must be members of STEP (which is free for graduate students) and be presenting on a STEP or STEP cosponsored panel. A maximum of 10 awards in the amount of $\$ 500$ will be granted each year.

Nominations due: April 15, 2019

Award Committee: Dorothy Daley, Chair, University of Kansas; Iza Ding, Pittsburg University; Erica Simmons, University of Wisconsin-Madison

\section{SECTION 16: WOMEN AND POLITICS RESEARCH}

Formed: 1986 / Dues: \$16 for students and $\$ 30$ for all other members

The purpose of this section is to foster the study of women and politics within the discipline of political science.

Website: http://connect.apsanet.org/groups/women-and-politicsresearch-section-16/

Chair: Shauna Shames, Rutgers University at Camden

Vice-Chair: Merike Blofield, University of Miami

Chair-Elect: Eileen Hunt Botting, Notre Dame University

Secretary: Amy Atchison, Valparaiso University

Treasurer: Caroline Beer, University of Vermont

Editor: Politics \& Gender: Mary Caputi, California State University, Long Beach

2019 Annual Meeting Program Chairs: Nandini Deo, Lehigh University and Eileen McDonagh, Northeastern University

Executive Council: Shan-Jan Sarah Liu, Newcastle University; Nandini Deo, Lehigh University; Nadia Brown, Purdue University; Nancy Hirschman, University of Pennsylvania; Cathy Wineinger, Rutgers University

\section{Best Dissertation Prize}

The best dissertation prize for the best dissertation on women and politics completed and accepted in the previous year.

Nominations due: March 1, 2019

Award Committee: TBA

Best Paper Award

The best paper award presented for the best paper presented at the previous year's annual meeting in the field of women and politics.

Nominations due: April 1, 2019
Award Committee: TBA

The Okin-Young Award in the Feminist Political Theory

The Okin-Young Award in Feminist Political Theory, cosponsored by Women and Politics, Foundations of Political Theory, and the Women's Caucus for Political Science, commemorates the scholarly, mentoring, and professional contributions of Susan Moller Okin and Iris Marion Young to the development of the field of feminist political theory. This annual award recognizes the best paper on feminist political theory published in an English language academic journal during the previous calendar year.

Nominations due: February 15, 2019

Award Committee: TBA

SECTION 17: FOUNDATIONS OF POLITICAL THEORY

Formed: 1987 / Dues: \$0 for students and \$10 for all other members

The Foundations of Political Theory Section exists to advance the linkage of political theory and philosophy with political science as a discipline. Foundations recognizes and encourages research and teaching that crosses intellectual and disciplinary boundaries. It stands at and seeks to support the intersection where philosophical, psychological, normative, and empirical approaches and problems meet. Foundations, as the name suggests, aims to study the more permanent dimensions of political life ranging from the design of institutions and political practices to the terms and concepts used to interpret the former. At the Foundations website, you will find information about the section, including its officers, its newsletter, and a bookstore where you can browse past and new titles in political theory. One new feature is a listing of job opportunities for political theorists and recent placements. If you are not already a member of the section, we hope that you will join us.

Website: http://apsanet.org/section17

Chair: Robyn Marasco, Hunter College, CUNY

Treasurer: Tamara Metz, Reed College

2019 Annual Meeting Program Chairs: Sonali Chakravarti, Wesleyan College; Alexander Hirsch, University of Alaska, Fairbanks

Executive Council: Arash Abizadeh, McGill University; Paulina Ochoa Espejo, Haverford College; Juliet Hooker, Brown University; James Ingram, McMaster University; Shirin Deylami, Western Washington University; Ainsley LeSure, Occidental College

\section{David Easton Award}

The David Easton Award is given for a book that broadens the horizons of contemporary political science by engaging issues of philosophical significance in political life through any of a variety of approaches in the social sciences and humanities.

Nominations due: February 15, 2019

Award Committee: Kevin Olson, University of California, Irvine; Lawrie Balfour, University of Virginia; Patchen Markell, Cornell University

\section{First Book Prize}

The First Book Award is given for a first book by a scholar in the early stages of his or her career in the area of political theory or political philosophy.

Nominations due: February 15, 2019

Award Committee: Margaret Kohn, University of Toronto; Lisa 
Ellis, University of Otago; Antonio Vazquez-Arroyo, Rutgers University

\section{Best Paper Award}

Best Paper Award is given for the best paper presented on a Foundations panel at the previous year's APSA Annual Meeting. Nominations are limited to presenters untenured.

Nominations due: February 15, 2019

Award Committee: Sharon Stanley, University of Memphis Andrew Dilts, Loyola Marymount University; Torrey Shanks, University of Toronto

The Okin-Young Award in the Feminist Political Theory

The Okin-Young Award in Feminist Political Theory, cosponsored by Women and Politics, Foundations of Political Theory, and the Women's Caucus for Political Science, commemorates the scholarly, mentoring, and professional contributions of Susan Moller Okin and Iris Marion Young to the development of the field of feminist political theory. This annual award recognizes the best paper on feminist political theory published in an English language academic journal during the previous calendar year.

Nominations due: February 15, 2019

Award Committee: Ainsley LeSure, Occidental College

SECTION 18: INFORMATION TECHNOLOGY AND POLITICS

Formed: 1988 / Dues: \$8 for student members and \$8 for all other members

The purpose of this section is to provide a forum for members with an interest in the use of computers, the internet, and multimedia in teaching, research, and policy applications in political science and all related subfields and disciplines.

Website: http://apsaitp.org

Chair: Ben Epstein, DePaul University

Vice-Chair: Cristian Vaccari, Loughborough University

Chair-Elect: Cristian Vaccari, Royal Holloway University

Secretary: George Robert Boynton, University of Iowa

Treasurer: Cecilia Manrique, University of Wisconsin-La Crosse

Editor: Journal of Information Technology and Politics: Michael Jensen, University of Canberra

2019 Annual Meeting Program Chair: Cristian Vaccari, Loughborough University

Executive Council: Jordan Brown, University of Texas; Filippo Trevisan, American University; David Morar, George Mason University; Lauren Copeland, Baldwin Wallace University; Andrew Chadwick, Loughborough University; Cristian Vaccari, Loughborough University; Ben Epstein, DePaul University; George Robert Boynton, University of Iowa; Terri Towner, Oakland University; Cecilia G. Manrique, University of Wisconsin-La Crosse

Best Dissertation in Information Technology and Politics The Best Dissertation Award recognizes the best dissertation in the area of information technology and politics.

Nominations due: April 1, 2019
Award Committee: TBA

\section{Best Conference Paper}

The Best Conference Paper Award recognizes the best conference paper in the area of information technology and politics. The contest is limited to articles presented at conferences in the previous calendar year.

Nominations due: April 1, 2019

Award Committee: Shelley Boulianne, MacEwan University

Best Published Article

The Best Published Article Award recognizes the best scholarly article published about information technology and politics. The contest is limited to articles published in the calendar year. The winner will receive a certificate and a check for the cost of one year's membership in the APSA and the ITP section.

Nominations due: April 1, 2019

Award Committee: Homero Gil de Zuniga, University of Vienna

\section{Best Book Award}

The Best Book Award recognizes the best book in the area of information technology and politics. The contest is limited to books published in the previous calendar year.

Nominations due: April 1, 2019

Award Committee: Joel Penney, Montclair State University

Best Student Paper Award

The Best Student Paper Award is presented to the best student paper in information technology and politics at the previous year's APSA.

Nominations due: April 1, 2019

Award Committee: TBA

Best Public Facing Scholarship Award

The Best Public Facing Scholarship Award is for the best publicfacing scholarship published in the previous calendar year. This includes blog posts and popular press publications intended for a broad public audience.

Nominations due: April 1, 2019

Award Committee: TBA

Best Information Technology Award

The Best Information Technology Award is for the best information technology, including hardware, software, scripts, packages, etc. Any nomination should explain why the candidate is appropriate for this category. Timing on this award is more flexible but nominations should indicate general use in the most current year.

Nominations due: April 1, 2019

Award Committee: TBA

\section{SECTION 19: INTERNATIONAL SECURITY}

Formed: 1988 / Dues: \$10 for all members

The purpose of this section is to encourage research and scholarship in international security and arms control, providing an opportunity for presentation of papers and discussion of theoretical and empirical work at APSA section meetings.

Website: https://connect.apsanet.org/s19 
Chair: TBA

Treasurer: TBA

2019 Annual Meeting Program Chair: Stephen Grenier, The Citadel

Kenneth N. Waltz Dissertation Award

ISAC will consider doctoral dissertations on any aspect of security studies with a submission date in calendaryear 2018. The committee welcomes nominations for theses on any aspect, and that deploy any approach (historical, quantitative, theoretical, policy analysis, etc.), in the field of security studies. Theses will be judged according to four criteria: originality in substance and approach, significance for scholarly and/or policy debates, rigor in approach and analysis, and power of expression.

Nominations due: TBA

\section{Award Committee: TBA}

Joseph J. Kruzel Memorial Award for Public Service

The Joseph J. Kruzel Memorial Award for Distinguished Public Service is awarded to a scholar with a distinguished career in national security affairs both as an academic and a public servant. It is given to memorialize Joseph Kruzel, a security studies scholar and Department of Defense policy official who was killed while on a diplomatic mission to Bosnia.

Nominations due: TBA

Award Committee: TBA

\section{SECTION 20: COMPARATIVE POLITICS}

Formed: 1988 / Dues: \$5 for student members and \$10 for all other members

The purpose of this section is to promote the comparative, especially cross-national, study of politics and to integrate work of comparativists, area studies specialists, and those interested in American politics.

Website: https://connect.apsanet.org/s2o/

Chair: TBA

Vice-Chair: TBA

Secretary / Treasurer: TBA

Editor: Comparative Politics Section Newsletter: TBA

2019 Annual Meeting Program Chairs: Karen Anderson, University College Dublin and Sam Handlin, Swarthmore College

Executive Council: Melani Cammett, Harvard University; Sara Binzer-Hobolt, London School of Economics; Kimuli Kasara, Columbia University; Rebecca Weitz-Shapiro, Brown University; Jennifer Gandhi, Emory University; Guillermo Trejo, University of Notre Dame

\section{Luebbert Book Prize}

Awarded annually for the best book published in the field of comparative politics during 2017 or 2018

Nominations due: TBA

Award Committee: TBA

Luebbert Article Prize

Awarded annually for the best article in the field of comparative politics during 2017 or 2018.
Nominations due: TBA

Award Committee: TBA

Sage Paper Prize

Awarded to the best paper in comparative politics presented at the 2018 annual meeting.

Nominations due: TBA

Award Committee: TBA

Lijphart/Przeworski/Verba Dataset Award

Awarded annually to a publicly-available dataset in the field of comparative politics.

Nominations due: TBA

Award Committee: TBA

SECTION 21: EUROPEAN POLITICS AND SOCIETY

Formed: 1989 / Dues: $\$ 5$ for students and $\$ 10$ for all other members

The purpose of the section is to promote comparative discussion, research and debate about the changing sociology of politics, the state, and social structures in modern Western Europe.

Website: https://connect.apsanet.org/s21/

Chair: Erik Jones, Johns Hopkins University

Chair-Elect: Jane Gingrich, University of Oxford

Treasurer: Johannes Lindvall, Lund University

Editor: European Politics and Society Newsletter: David Art, Tufts University; Alexander Jakubow, New Mexico State University

2019 Annual Meeting Program Chair: Jane Gingrich, University of Oxford

Executive Council: Pepper Culpepper, University of Oxford; R Daniel Kelemen, Rutgers University; Dorothee Bohle, European University Institute; Silja Häusermann, University of Zurich; Wade Jacoby, Brigham Young University; Kimberly Morgan, George Washington University; Mark Vail, Tulane University; Carol Mershon, University of Virginia; Amel Ahmed, University of Massachusetts

Best Book Award

The Best Book Award is given for the best book on European politics and society published in the previous year.

Nominations due: March 1, 2019

Award Committee: Christopher Bickerton, Chair, University of Cambridge; Tim Haughton, University of Birmingham; Aida Hozic, University of Florida

\section{Ernst B. Haas Best Dissertation Award}

The Ernst B. Haas Best Dissertation Award is given for the best dissertation on European politics and society filed during the previous year.

Nominations due: March 1, 2019

Award Committee: Mark Vail, Tulane University; Filippo Tronconi, University of Bologna; Sara Watson, Oklahoma State University

Best Article Award

This award is given for the best article dealing with European politics and society published in the last year. 
Nominations due: March 1, 2019

Award Committee: Sabine Saurugger, Sciences Po, Grenoble; Paolo Graziano, University of Padova; Muiris MacCarthaigh, Queen's University, Belfast

\section{Best Paper Award}

The Best Paper Award is given for the best paper given on European Politics and Society Section-sponsored panels at the previous APSA Annual Meetings.

Nominations due: March 1, 2019

Award Committee: Sophie Meunier, Princeton University; Liesbet Hooghe, University of North Carolina; Christina J. Schneider, University of California, San Diego

\section{Peter Mair Memorial Travel Award}

The Peter Mair Memorial Award will fund the travel of two young scholars to attend the APSA Annual Meeting. Named in memory of Professor Peter Mair, one of the foremost scholars of European politics, the award is meant explicitly to enable young scholars of European politics without adequate funding to present a paper in one of the panels organized by the EPS Section. First-time APSAattendants who are graduate students or junior professors from underfunded European universities (notably in the East and South) are prioritized, but senior scholars from such institutions as well as junior scholars from underfunded non-European universities (including the US) are also considered. Applicants are expected to also apply to all other travel funds they are eligible for, including their department/university, national science foundations, and the APSA Travel Fund. The awards are set at a maximum of $\$ 1,000$ each, but partial/matching funding is possible too.

Nominations due: May 1, 2019

Award Committee: Mark A. Pollack, Temple University; Carol A. Mershon, University of Virginia; Miguel Otero Iglesias, Elcano Royal Institute

\section{SECTION 22: STATE POLITICS AND POLICY}

Formed: 1989 / Dues: \$27 for students and professional members

The purpose to this section is to further our understanding of the American states including their institutions, political actors, policies, and local, national, and international influence.

Website: http://politicalscience.olemiss.edu/state-politics-andpolicy

Chair: Christopher Z. Mooney, University of Illinois at Springfield

Secretary: Craig Burnett, Hofstra University

Treasurer: Shanna Pearson-Merkowitz, University of Rhode Island

Editors: State Politics and Policy Quarterly: Chris Bonneau, University of Pittsburgh and Kris Kanthak, University of Pittsburgh

Editor: State Politics and Policy Newsletter: Craig Burnett, Hofstra University

2019 Annual Meeting Program Chair: James C. Battista, SUNY University at Buffalo

Executive Council: Michael Nelson, Pennsylvania State University; Marjorie Sarbaugh-Thompson; Wayne State University; Jason Windett, University of North Carolina at Charlotte; Rebecca Kreitzer, University of North Carolina at Chapel Hill; Becki Scola, St. Joseph's University
Career Achievement Award

The Career Achievement Award is given annually to a political scientist who has made a significant lifetime contribution to the study of politics and public policies in the American states.

Nominations due: TBA

Award Committee: Peverill Squire, Chair, University of Missouri, Columbia; Martha E. Kropf, University of North Carolina, Charlotte; David L. Leal, University of Texas, Austin

Virginia Gray Book Award

To be awarded annually to the best political science book published on the subject of US state politics or policy in the preceding three calendar years. Thus, books would be eligible to be considered for the award for three years (e.g., for the 2019 award, books with a copyright of 2016, 2017, and 2018 would be eligible for nomination).

Nominations due: TBA

Award Committee: Chris Witko, Chair, Penn State University; Laurel Harbridge-Yong, Northwestern University; Robynn Kuhlmann, University of Central Missouri

\section{Christopher Z. Mooney Best Dissertation Prize}

This annual award is given to the author of the best $\mathrm{PhD}$ dissertation in American state politics and policy completed during the previous calendar year. The winner receives a plaque and $\$ 1000$. Support for this prize comes form the annual return of the endowed Mooney Fund.

Nominations due: TBA

Award Committee: Tracy Osborn, Chair, University of Iowa; Robert Lowry, University of Texas, Dallas; Antoine Yoshinaka, SUNY University at Buffalo

\section{SPPQ Award for Best Paper Award}

This annual award is given to the author(s) of the best paper on state politics and policy presented at any professional meeting in the previous calendar year. The award committee may designate separate awards for papers presented by graduate students with no faculty authorships and for papers with solely faculty or faculty and graduate student participation. Graduate student winners will receive a plaque and $\$ 100$ and faculty winners will receive a plaque.

\section{Nominations due: TBA}

Award Committee: Renee Van Vechten, Chair, University of Redlands; Adam Brown, Brigham Young University; Michael G. Miller, Barnard College

\section{Best Published Paper Award}

The award recognizes the best journal article on US state politics or policy published during the previous calendar year in any peer-reviewed journal (book reviews, review essays, and chapters published in edited volumes are not eligible).

Nominations due: TBA

Award Committee: Christopher Warshaw, Chair, George Washington University; Rebecca Kreitzer, University of North Carolina at Chapel Hill; Lynda Powell, Rochester University

\section{SECTION 23: POLITICAL COMMUNICATION}

Formed: 1989 / Dues: \$0 for student members and \$8 for all other members

The purpose of this section is to foster the study of political communications within the discipline of political science 
including research on mass media, telecommunications policy, new media technologies, and the process of communicating and understanding.

Website: http://politicalcommunication.org

Chair: Kate Kenski, University of Arizona

Vice Chair: Tim Groeling, University of California, Los Angeles

Secretary/Treasurer: Ashley Muddiman, University of Kansas

Editor: Political Communication: Claes de Vreese, University of Amsterdam

2019 Annual Meeting Program Chair: Joshua Darr, Louisiana State University

Executive Council: Emily Sydnor, Southwestern University; Thomas Billard, University of Southern California

Doris Graber Outstanding Book Award

The Doris Graber Outstanding Book Award is given to the most outstanding book in the field of political communication that was published in the past decade. The nominated book and a nomination letter should be sent to all three members of the award committee. The nomination letter should clearly explicate how the book has made a significant theoretical, methodological, and/or empirical contribution to political communication scholarship in the last decade. Copies of book reviews may also be included with the nomination letter and book.

Nominations due: March 1, 2019

Award Committee: Rune Slothuus, Aarhus University; Jamie Settle, The College of William \& Mary; Emily Syndor, Southwestern University

Paul Lazarsfeld Best Paper Award

The Paul Lazarsfeld Award recognizes the best paper on political communication presented at the previous year's APSA Annual Meeting or political communication preconference.

Nominations due: March 1, 2019

Award Committee: Jennifer Pan, Stanford University; Benjamin Toff, University of Minnesota; Jason Turcotte, California Polytechnic University, Pomona

Timothy E. Cook Best Graduate Student Paper Award

The Timothy E. Cook awards recognizes the best paper on political communication presented by a graduate student at the previous year's APSA Annual Meeting or political communication preconference.

Nominations due: March 1, 2019

Award Committee: Danielle Vinson, Furman University; Brian Weeks, University of Michigan; Kathleen Searles, Louisiana State University

\section{Thomas E. Patterson Best Dissertation Award}

The Thomas E. Patterson Best Dissertation Award recognizes the best dissertation completed in the field of political communication in the previous year. Nominations for the award should be made by the adviser of the dissertation or by a faculty member from the department in which the dissertation was completed. Nomination letters should explain the central argument advanced by the dissertation and specify its original contribution to the field. Letters should be no more than one page in length. Eligible dissertations must have been defended successfully in the calendar year preceding the award (e.g., candidates whose degrees were awarded in 2018 will be eligible for the 2019 dissertation award) The nominating letter and digital copies of the dissertation, abstract of the dissertation (50o words or less), and the nominee's curriculum vita (with current address) should be sent to the chair of the dissertation award committee.

Nominations due: March 1, 2019

Award Committee: Nick Anstead, London School of Economics; Jenifer Whitten-Woodring; Georgia Kernell, University of California, Los Angeles

Walter Lippmann Best Published Article Award

Recognizes the best article published in the field of political communication in the previous calendar year.

Nominations due: March 1, 2019

Award Committee: Shelley Boulianne, MacEwan University; John Ryan, Stony Brook University; Nathan Kalmoe, Louisiana State University; Mona Kleinberg, University of Massachusetts, Lowell

Murray Edelman Lifetime Distinguished Career Award

The Murray Edelman Distinguished Career Award recognizes a lifetime contribution to the study of political communication. The award is now given only in odd-numbered years.

Nominations due: March 1, 2019

Award Committee: Rasmus Kleis Nielson; Markus Prior, Princeton University; Holli Semetko, Emory University

\section{SECTION 24: POLITICS AND HISTORY}

Formed: 1989 / Dues: \$0 for student members and \$10 for all other members

The purpose of this section is to bring together political scientists interested in historical issues and problems drawing from almost every traditional disciplinary subfield.

Website: http://apsanet.org/section24

Chair: Nancy Bermeo, Princeton University

Chair-Elect: Adam Sheingate. Johns Hopkins University

Secretary/Treasurer: Robert Mickey, University of Michigan

Editor: CLIO: Shamira Gelbman, Wabash College

2019 Annual Meeting Program Chairs: Erik Martinez Kuhonta, McGill University and Priscilla Yamin, University of Oregon

Executive Council: Mala Htun, University of New Mexico; Debra Thompson, University of Oregon; David E. Wilkins, University of Minnesota; Daniel Wirls, University of California, Santa Cruz; Julia Azari, Marquette University; Evgeny Finkel, Johns Hopkins University SAIS; Jonathan Obert, Amherst College; Sarah Staszak, Princeton University

\section{J. David Greenstone Book Prize}

The J. David Greenstone Book Prize recognizes the best book in history and politics in the past two calendar years.

Nominations due: March 1, 2019

Award Committee: Paul Frymer, Chair, Princeton University; Eleonora Passotti, University of California, Santa Cruz; Jeffrey Selinger, Bowdoin College 
Mary Parker Follett Prize

The Mary Parker Follett Prize recognizes the best article on politics and history published in the previous year.

Nominations due: March 1, 2019

Award Committee: Jason Whittenberg, Chair, University of California, Berkeley; Jennifer Dixon, Villanova University; Nicole Mellow, Williams College

Walter Dean Burnham Dissertation Award

The Walter Dean Burnham Award is given for the best dissertation in the field of politics and history.

Nominations due: March 1, 2019

Award Committee: Margaret Weir, Chair, Brown University; Jason Brownlee, University of Texas at Austin; Hillel Soifer, Temple University

\section{SECTION 25: POLITICAL ECONOMY}

Formed: 1990 / Dues: \$0 for student members and \$10 for all other members

The purpose of this section is to promote teaching and research in the areas of representation and electoral systems, and to encourage communication among persons interested in these fields within the association and with related disciplines.

Website: http://apsanet.org/section25

Chair: Kanchan Chandra, New York University

Secretary/Treasurer: George Krause, University of Georgia

Editors: The Political Economist Newsletter: John Alquist, University of California, San Diego; Christina Schneider, University of California, San Diego; Megumi Naoi, University of California, San Diego

2019Annual Meeting Program Chairs: Scott Abramson, University of Rochester and Alisha Holland, Princeton University

Executive Council: Lisa Blaydes, Stanford University; Layna Mosley, University of North Carolina at Chapel Hill; Elizabeth Maggie Penn, Emory University; Jan Pierskalla, Ohio State University; David Skarbek, Brown University; Hye Young You, New York University

McGillivray Best Paper Award

The McGillivray Best Paper Award is given for the best paper in political economy presented at the previous year's APSA Annual Meeting.

\section{Nominations due: TBA}

Award Committee: TBA

Michael Wallerstein Award

The Michael Wallerstein Award is given for the best published article in political economy in the previous calendar year.

Nominations due: TBA

Award Committee: TBA

Mancur Olson Best Dissertation Award

The Best Dissertation Award, named for Mancur Olson, is given for the best dissertation in political economy completed in the previous two years.

Nominations due: TBA

\section{Award Committee: TBA}

William H. Riker Book Award

The Best Book Award, named for William H. Riker, is given for the best book on political economy published during the past three calendar years.

Nominations due: TBA

Award Committee: TBA

\section{SECTION 27: NEW POLITICAL SCIENCE}

Formed: 1992 / Dues: \$5 for students and $\$ 30$ for all other members

The purpose of this section is to help make the study of politics relevant to the struggle for a better world.

Website: http://apsanet.org/section27

Chair: Nancy S. Love, Appalachian State University

Secretary: Sarah M. Surak, Salisbury University

Treasurer: Clyde W. Barrow, University of Texas, Rio Grande Valley

Editor: New Political Science: A Journal of Politics \& Culture: Jocelyn M. Boryczka, Fairfield University

2019 Annual Meeting Program Chair: Dean Snyder, Antioch College

Caucus Representatives: Daniel O'Connor, California State University, Long Beach; Claire Snyder-Hall, Independent Scholar

Membership Director: Robert Kirsch, Arizona State University

Web and Social Media Coordinator: Riley Barrett, Independent Scholar

Witnesses and Advocates Special Committee: Judith Grant, Ohio University

Christian Bay Award

The Christian Bay Award recognizes the best paper presented on a new political science panel at the previous year's annual meeting.

Nominations due: April 1, 2019

Award Committee: Alison Gash, Co-Chair, University of Oregon; Priscilla Yamin, Co-Chair, University of Oregon; Matthew Evans, Northwest Arkansas Community College; Lucrecia Garcia-Iommi, Fairfield University

Richard Cloward and Frances Fox Piven Award

The Richard Cloward and Frances Fox Piven Award recognizes an activist group, in the region of the annual meeting, that puts the ideals of the New Political Science Section, 'to make the study of politics relevant to the struggle for a better world,' into practice.

Nominations due: April 1, 2019

Award Committee: Margaret Groarke, Manhattan College; Sean Parson, Northern Arizona University; Edwin Dan Jacob, Arkansas State University; Frances Fox Piven, CUNY Graduate Center

Charles A. McCoy Career Achievement Award

The Charles A. McCoy Career Achievement Award recognizes a progressive political scientist who has had a long, successful career as a writer, teacher, and activist.

Nominations due: April 1, 2019

Award Committee: Cynthia Enloe, Chair, Clark University; 
Bradley MacDonald, Colorado State University; Manal Jamal, James Madison University

\section{Michael Harrington Book Award}

The Michael Harrington Book Award recognizes an outstanding book that demonstrates how scholarship can be used in the struggle for a better world.

Nominations due: April 1, 2019

Award Committee: Gordon Lafer, Chair, University of Oregon; Timothy W. Luke, Virginia Tech University; Pamela Stricker, California State University-San Marcos; Wendy Wright, Bridgewater State University

\section{Stephen Eric Bronner Dissertation Award}

For an outstanding political science dissertation finished within the previous year which exemplifies the commitment to use scholarship in the struggle for a better world.

Nominations due: April 1, 2019

Award Committee: Rafael Khachaturian, University of Pennsylvania; Laura Katz Olson, Lehigh University; Peter Wagner, University of Wisconsin-Whitewater; Stephen E. Bronner, Rutgers University

\section{SECTION 28: POLITICAL PSYCHOLOGY}

Formed: 1993 / Dues: \$5 for student members and \$10 for all other members

The purpose of this section to facilitate communication across subfields and disciplinary boundaries among individuals interested in the relationship between political and psychological processes.

Website: https://connect.apsanet.org/s28/

Chair: Daniel Hopkins, University of Pennsylvania

Chair-Elect: Efren O. Perez, University of California, Los Angeles

Treasurer: Melissa Sands, University of California, Merced

Communications Officer: Michele Margolis, University of California, Merced

2019 Annual Meeting Program Chairs: Ashley Jardina, Duke University and Mara Ostfeld, University of Michigan

Executive Council: Tali Mendelberg, Princeton University

Robert E. Lane Award

Robert E. Lane Award for the best book in political psychology published in the past year.

\section{Nominations due: TBA}

Award Committee: Samara Klar, Chair, University of Arizona; Yanna Krupnikov, Stony Brook University; Virginia Sapiro, Boston University

\section{Best Dissertation Award}

The Best Dissertation Award is given for the best dissertation in political psychology filed during the previous year. Send an electronic copy of the dissertation to each committee member. Self-nominations are accepted. All nominations should include a letter of support from the chair of the dissertation committee that addresses the contribution of the dissertation to the field of political psychology.

Nominations due: TBA
Award Committee: Rick Lau, Chair, Rutgers University; KrisStella Trump, Social Science Research Council; Adam Thal, Yale University

\section{Best Paper Award}

The Best Paper Award is given to the most outstanding paper in political psychology delivered at the previous year's annual meeting.

Nominations due: TBA

Award Committee: Jennifer Wolak, University of Colorado, Boulder; Michael Sances, University of Memphis; Bert Bakker, Amsterdam School of Communication Research

\section{Distinguished Junior Scholar Award}

The APSA Political Psychology section gives Distinguished Junior Scholar Awards as grants to junior scholars (graduate students or those no more than seven years since receiving their $\mathrm{PhD}$ ) to help fund their travel to the APSA meeting. Applicants should send their $\mathrm{CV}$, a one-page single-spaced statement describing their work, and evidence that they have been accepted on the APSA program, either as paper giver or poster-presenter.

\section{Nominations due: TBA}

Award Committee: Jane Junn, University of Southern California; Alex Coppock, Yale University; Ali Valenzuela, Princeton University; Christopher Johnston, Duke University

\section{Political Psychology Career Award}

The Political Psychology Hazel Gaudet Erskine Career Achievement Award is awarded biennially to recognize a scholar whose lifetime scholarship and service to the profession has made an outstanding contribution to the field of political psychology.

Nominations due: TBA

Award Committee: Howard Lavine, University of Minnesota; Deborah Schildkraut, Tufts University; Loren Collingwood, University of California, Riverside

\section{SECTION 29: POLITICAL SCIENCE EDUCATION}

Formed: 1993 / Dues: \$0 for student members and \$12 for all other members

The purpose of this section is to promote exemplary undergraduate teaching within the political science discipline and to the scholarship of teaching. The section is especially dedicated to increasing the use of innovative teaching methods, particularly those rooted in experience (internships, service learning, simulations, and study abroad) and the evaluation of such methods.

Website: http://web.apsanet.org/teachingcivicengagement/ political-science-educator/

Chair: Patrick McKinlay, Morningside College

Vice-Chair: Terry Gilmour, Midland College

Secretary: Terry Gilmour, Midland College

Treasurer: Joseph Roberts, Roger Williams University

Editor: The Political Science Educator Newsletter: Bobbi Gentry, Bridgewater College

2019 Annual Meeting Program Chair: Mary McHugh, Merrimack College and Elizabeth Matto, Rutgers University

Executive Council: Elizabeth Bennion, Indiana University, South 
Bend; Boris Ricks, California State University, Northridge; Thomas Rigenberg, Rockhurst University; Michael Rogers, Arkansas Tech University; Donald Gooch, Stephen F. Austin University; Sherri Wallace, University of Louisville; Bobbi Gentry, Bridgewater College; Sherri Wallace, University of Louisville

The Craig T. Brians Award for Excellence in Undergraduate Research and Mentorship

Established in 2014, this award will be awarded at the PSE Section reception at the APSA Annual Meeting. The award will be given to faculty members who demonstrate commitment to and excellence in encouraging and developing scholarship among undergraduate students, and in mentoring undergraduate students in preparation for graduate school or public affairs-related careers. Evidence for these commitments may include, but are not limited to, formal and informal supervision of undergraduate student original research, collaborating with undergraduate students on original research projects, assisting undergraduate students with public presentations and/or publication of work, and accompanying students to academic conferences. In honor of the person for whom the award is named, preference will also be given to faculty members who engage in developing undergraduate scholarship through enhancing information literacy.

Nominations due: April 1, 2019

Award Committee: Carlos Huerta, Texas A\&M University; Fletcher McClellan, Elizabethtown College; Allison McCartney, Towson University

The Best APSA Conference Paper Award

This award is given annually at the section meeting during the APSA Annual Meeting to the author(s) who present at the previous year's APSA Annual Meeting, either at a panel or poster session.

Nominations due: April 1, 2019

Award Committee: Michael Rogers, Arkansas Tech University; Bobbi Gentry, Bridgewater College; Terry Gilmour, Midland College

The Lifetime Achievement Award

This award may be given at the annual section meeting held at the APSA Annual Meeting. The awardee must have a strong record of long-standing, exceptional, and extensive contributions to the goals of the section, including the promotion of the teaching and learning in the discipline and the scholarship of teaching. Any section member may submit a nomination letter to the Executive Committee. Nominations are due by April 1. The Executive Committee will determine if a nominee is eligible and will decide by June 1 if the award will be given. This award does not have to be given every year.

Nominations due: April 1, 2019

Award Committee: Sherri Wallace, Chair, University of Louisville; Elizabeth Bennion, Indiana University, South Bend; Boris Ricks, California State University, Northridge; Thomas Rigenberg, Rockhurst University; Michael Rogers, Arkansas Tech University; Donald Gooch, Stephen F. Austin University; Sherri Wallace, University of Louisville; Bobbi Gentry, Bridgewater College

The Distinguished Service Award

This award may be given at the section meeting held at the APSA Annual Meeting. The awardee must have a strong record of exceptional and extensive contributions to the goals of the section, including the promotion of teaching and learning in the discipline and the scholarship of teaching. Any section member may submit a nomination letter to the Award Committee. The Award Committee will determine if a nominee is eligible and will decide by June 1 if the award will be given. This award does not have to be given every year.

\section{Nominations due: April 1, 2019}

Award Committee: Sherri Wallace, Chair, University of Louisville; Elizabeth Bennion, Indiana University, South Bend; Boris Ricks, California State University, Northridge; Thomas Rigenberg, Rockhurst University; Michael Rogers, Arkansas Tech University; Donald Gooch, Stephen F. Austin University; Sherri Wallace, University of Louisville; Bobbi Gentry, Bridgewater College

\section{SECTION 30: POLITICS, LITERATURE, AND FILM}

Formed: 1993 / Dues: \$0 for students and \$5 for professional members

The study of literature and film offers political scientists a particularly stimulating mode of inquiry into political institutions and principles, and into the ways of life that sustain them and are, in turn, shaped by them. Indeed, the creation of this division is itself a sign of the complex and changing landscape of the study of politics. The section explores the way in which literature-broadly understood to include film and other literary genres-provides unique insights into the nature of political life and the study of politics.

Website: http://apsanet.org/section3o

Chair: Linda Beail, Point Loma Nazarene University

Chair-Elect: Robert Watkins, Columbia College, Chicago

2019 Annual Meeting Program Chair: Linda Beail, Point Loma Nazarene University

Wilson Carey McWilliams Award

The Wilson Carey McWilliams Award is given for the best paper presented at the APSA Annual Meeting.

Nominations due: TBA

Award Committee: Davide Panagia, University of California, Los Angeles; Lori Marso, Union College; Morton Schoolman, SUNY at Albany

\section{SECTION 31: FOREIGN POLICY}

\section{Formed: 1993 / Dues: \$10 for students and professional members}

The Foreign Policy Section is the organization for those interested in multilevel approaches to the study of international relations. The section emphasizes individual, role, organizational, bureaucratic, societal, and/or state as well as situational and system level variables in foreign policy analyses. Members of the section employ a wide range of approaches, including historical, normative, rational, behavioral, liberal, institutional, psychological, and constructivist. Section members emphasize comparative as well as American studies of foreign policy. And the section recognizes the contributions of practitioners as well as academics in a broad range of professions and disciplines, for example: communications, economics, diplomacy, government, history, political science, public opinion polling, philosophy, psychology, and sociology.

Website: http://apsanet.org/section31

Chair: TBA 
Chair-Elect: TBA

\section{Secretary/ Treasurer: TBA}

2019 Annual Meeting Program Chair: Megan Stewart, American University

Executive Council: TBA

\section{Distinguished Scholar Award}

Recognizes a history of distinguished scholarship in the field of foreign policy. This award will be given biennially, alternating with the section's best book award.

Nominations due: TBA

Award Committee: TBA

Best Paper Award

Presented to the best paper on foreign policy presented at the previous year's APSA Annual Meeting.

Nominations due: TBA

Award Committee: TBA

Best Graduate Student Paper Award

For outstanding graduate student papers presented at the APSA Annual Meeting that are relevant to the study of foreign policy. Nominations should be sent to the chair of the section.

Nominations due: TBA

Award Committee: TBA

\section{Best Book Award}

Recognizes the best book in the field of foreign policy. This award is biennial and alternates with the Distinguished Scholar Award.

Nominations due: TBA

Award Committee: TBA

\section{SECTION 32: ELECTIONS, PUBLIC OPINION,} AND VOTING BEHAVIOR

Formed: 1994 / Dues: \$12 for student members and \$18 for all other members.

The purpose of this section is to promote interest in teaching and research on elections, electoral behavior, public opinion, voting turnout, and political participation, both within the United States and in comparative perspective.

Website: http://connect.apsanet.org/s32/

Chair: Elizabeth Zechmeister, Vanderbilt University

Vice-Chair: Andre Blais, Université de Montréal

Treasurer: Jennifer Wolak, University of Colorado, Boulder

Editor: Political Behavior: David Peterson, Iowa State University

Communications Director: Bethany Albertson, University of Texas

2019 Annual Meeting Program Chairs: Peter Loewen, University of Toronto and Natalie Masouka, University of California, Los Angeles

Executive Council: Patrick Fournier, Université de Montréal; Shana Gadarian, Syracuse University; Quin Monson, Brigham Young University; Camille Burge, Villanova University; Jonathan Ladd, Georgetown University; David Nickerson, Temple University
Philip E. Converse Book Award

Awarded annually to the authors of an outstanding book published at least five years ago.

Nominations due: March 1, 2019

Award Committee: Caroline Tolbert, Chair, University of Iowa; Ed Fieldhouse, University of Manchester; Lynn Vavreck, University of California, Los Angeles

Emerging Scholars Award

Awarded to the top scholar in the field who is within ten years of her or his $\mathrm{PhD}$.

Nominations due: March 1, 2019

Award Committee: Samara Klar, Chair, University of Arizona; Stephen Mockabee, University of Cincinnati; Rebecca WeitzShapiro, Brown University

\section{Best Paper Award}

Awarded annually for the best paper delivered at one of the section's panels at the previous year's APSA Annual Meeting.

Nominations due: March 1, 2019

Award Committee: James Garand, Chair, Louisiana State University; Karen Jusko, Stanford University; Tyson KingMeadows, University of Maryland Baltimore County

Best Article in Political Behavior

Awarded for the best article published in Political Behavior in the previous calendar year.

Nominations due: March 1, 2019

Award Committee: David Kimball, Chair, University of MissouriSt. Louis; Sunshine Hillygus, Duke University; Lilliana Mason, University of Maryland

John Sullivan Award

Awarded for the best paper presented by a graduate student at one of the section's panels at the previous year's APSA Annual Meeting.

Nominations due: March 1, 2019

Award Committee: Cindy Kim, Chair, Vanderbilt University; Christina Farhart, Carleton College; Israel Waismel-Manor, University of Haifa

\section{Graduate Student Travel Awards}

Awarded to graduate students who are authors or coauthors of papers presented on a section panel at this year's APSA Annual Meeting.

Nominations due: March 31, 2019

Award Committee: Adam Brown, Chair, Brigham Young University; LaFleur Stephens, Princeton University; David Lublin, American University

\section{SECTION 33: RACE, ETHNICITY AND POLITICS}

Formed: 1995 / Dues: \$0 for student members and \$20 for all other members

The purpose of this section is to foster communication among scholars, recognize leadership in the field, facilitate research and publication opportunities, encourage undergraduate and student interest, and create a permanent forum for developing and refining appropriate theoretical models in the study of race and ethnicity. 
Website: http://www.apsarep.org

Chair: Kerry L. Haynie, Duke University

Co-Chair: Marisa Abrajano, University of California, San Diego

Secretary: Andrew Flores, University of California, Los Angeles

Treasurer: Christina Greer, Fordham University

Editors: Journal of Race and Ethnic Politics: Marisa Abrajano, University of California, San Diego and Jane Junn, University of Southern California

Editor: REP Newsletter: Hannah Walker, Rutgers University

2019 Annual Meeting Program Chairs: Rene Rocha, University of Iowa; Pearl Ford Dowe, University of Arkansas

Executive Council: Christina Bejarano, University of Kansas; Karam Dana, University of Washington, Bothell; Alexandra Filindra, University of Illinois Chicago; Chris Haynes, University of New Haven; Evelyn Simien, University of Connecticut; Pearl Ford Dowe, University of Arkansas; Lorrie-Frasure-Yokley, University of California, Los Angeles; Jessica Lavariega-Monforti, California Lutheran University; Jennifer Merolla, University of California, Riverside

Graduate Student Representative: Sara Sadhwani, University of Southern California

\section{Best Book Award}

The Best Book Award recognizes the very best research exploring the multiple junctures between politics and issues of race, ethnicity, immigration, and indigeneity, as well as their intersections with other axes of identity and marginalization. We seek nominations for books that broadly focus on racial and ethnic politics, from scholars across all sub-fields of political science and allied disciplines. Single- and coauthored books, monographs, and textbooks will be considered. Books published/copyrighted in calendar year 2018 are eligible for the prize. Books that were nominated in previous years are not eligible and should not be renominated.

Nominations due: April 1, 2019

Award Committee: Efren Perez, University of California, Los Angeles; Shatema Threadcraft, Dartmouth College; Spencer Piston, Boston University

Best Dissertation Award

The Best Dissertation Award is given for the best American dissertation on race, ethnicity, and politics accepted in the previous year.

Nominations due: April 30, 2019

Award Committee: Ismael White, Duke University; LaFleur Stephens, Princeton University; Valeria Sinclair-Chapman, Purdue University

\section{Best Paper Award}

The Best Paper Award is given for the best paper on race, ethnicity, and politics presented at the previous year's APSA Annual Meeting.

Nominations due: TBA

Award Committee: Pei-te Lien, University of California, Santa Barbara; Eric McDaniel, University of Texas at Austin; Christian Dyogi Phillips, Ohio State University

Mark Q. Sawyer Memorial Scholarship in Comparative Race
Politics

Recognizes scholarship that is closely tied to the research of the late Mark Q. Sawyer.

\section{Nominations due: TBA}

Award Committee: Andra Gillspie, Emery University; Lorrie Frasure-Yokley, University of North Carolina, Los Angeles; Tyson King-Meadows, University of Maryland, Baltimore County

SECTION 34: INTERNATIONAL HISTORY AND POLITICS Formed: 1999 / Dues: \$0 for student members and \$10 for all other members

The purpose of this section is to promote the study of international history and politics, to disseminate research results; to encourage interdisciplinary conversations between political scientists and historians, and to advance the development, dissemination, integration, and application of qualitative and historiographical methodologies.

Website: http://connect.apsanet.org/s34/

Chair: Cecelia Lynch, University of California, Irvine

Vice Chair: Stacie Goddard, Wellesley College

Secretary/Treasurer: Harris Mylonas, George Washington University

Newsletter Editors: International History and Politics Newsletter Peter Harris, Colorado State University and Tom Le, Pomona College

2019 Annual Meeting Program Chair: Stephen Nelson, Northwestern University

Executive Council: Jeffry Colgan, Brown University; Fiona Adamson, SOAS University of London; Bridgett Coggins, University of California, Santa Barbara; Narendra Subramanian, McGill University; Joseph M. Parent, Philip J. Howe, Adrian College

Robert L. Jervis and Paul W. Schroeder Best Book Award

The Robert L. Jervis and Paul Schroeder Best Book Award for the best book on international history and politics. This award may be granted to a single- or coauthored book, or to an edited volume. The award will be given to works published in the calendar year prior to the year of the annual meeting at which the award is presented. The copyright date of a book will establish the relevant year. Hence, books with a 2018 copyright date will be eligible for the award presented at the 2019 APSA meeting. Nominations for the JervisSchroeder Book award (including three copies of cover letters and books) should be sent directly to the award committee members.

Nominations due: February 28, 2019

Award Committee: Catherine Lu, McGill University; Mlada Bukovansky, Smith College; John Duffield, Georgia State University

Outstanding Article Award in International History and Politics The Outstanding Article Award in International History and Politics recognizes exceptional peer-reviewed journal articles representing the mission of the International History and Politics Section, including innovative work that brings new light to events and processes in international politics, encourages interdisciplinary conversations between political scientists and historians, and advances historiographical methods. The award is 
given to a published article that appeared in print in the calendar year preceding the annual meeting at which the award is presented. It may be granted to an article that is single- or coauthored. The year of final journal publication establishes eligibility. Nominations including a brief description of the significance of the article and a digital copy of the article should be sent to all award committee members before the annual deadline.

Nominations due: January 31, 2019

Award Committee: Ido Oren, Chair, University of Florida; Brendan Green, University of Cincinnati; Cheryl Shanks, Williams College

\section{SECTION 35: COMPARATIVE DEMOCRATIZATION}

Formed: 2000 / Dues: \$0 for student members and \$8 for all other members

The Comparative Democratization Section exists to promote the analysis of the origins, processes, and outcomes of democratization among nations, spur communication among political scientists whose scholarship focuses on particular world regions, and stimulate greater involvement within APSA of political scientists working in various areas like Africa, the Middle East, Latin America, the Far East, Europe, and the countries of the former Soviet Union.

Website: http://www.compdem.org

Chair: TBA

Vice Chair: TBA

Secretary: TBA

Treasurer: TBA

Newsletter Editor: APSA-CD: TBA

2019 Annual Meeting Program Chair: Mike Miller, George Washington University

\section{Best Article Award}

Single- or coauthored articles focusing directly on the subject of democratization and published in 2018 are eligible. Nominations and self-nominations are encouraged. Copies of the article should be sent by email to each of the committee members.

\section{Nominations due: TBA}

Award Committee: TBA

Best Book Award

Given for the best book in the field of Comparative Democratization published in 2018 (authored, coauthored, or edited).

Nominations due: TBA

\section{Award Committee: TBA}

\section{Best Fieldwork Award}

This prize rewards dissertation students who conduct especially innovative and difficult fieldwork. Scholars who are currently writing their dissertations or who complete their dissertations in 2018 are eligible. Candidates must submit two chapters of their dissertation and a letter of nomination from the chair of their dissertation committee describing the fieldwork. The material submitted must describe the fieldwork in detail and should provide one or two key insights from the evidence collected in the field. The chapters may be sent electronically or in hardcopy directly to each committee member.

Nominations due: TBA

\section{Award Committee: TBA}

\section{Best Paper Award}

Given to the best paper on comparative democratization presented at the previous year's APSA Annual Meeting. Papers must be nominated by panel chairs or discussants.

Nominations due: TBA

Award Committee: TBA

\section{Juan Linz Best Dissertation Award}

Given for the best dissertation in the comparative study of democracy completed and accepted in the two calendar years immediately prior to the APSA Annual Meeting where the award will be presented ( 2017 or 2018 for the 2019 Annual Meeting). The prize can be awarded to analyses of individual country cases as long as they are clearly cast in a comparative perspective. A hardcopy of the dissertation, accompanied by a letter of support from a member of the dissertation committee should be sent to each member of the prize selection committee.

Nominations due: TBA

Award Committee: TBA

\section{SECTION 36: HUMAN RIGHTS}

Formed: 2000 / Dues: \$0 for student members and \$10 for all other members

The Human Rights Section was established to encourage scholarship and facilitate exchange of data and research findings on all components of human rights (e.g., civil, political, economic, social, cultural, environmental), their relationship, determinants and consequences of human rights policies, structure and influence of human rights organizations, development, implementation, and impact on international conventions, and changes in the international human rights regime.

Website: http://apsahumanrightssection.blogspot.com

Chair: Bethany Barratt, Roosevelt University

Vice Chair: Brooke Ackerly, Vanderbilt University

Chair-Elect: Brian Greenhill, University of Albany, SUNY

Secretary: Gio Altamirano Rayo, Carnegie Mellon University

Treasurer: Michael Struett, North Carolina State University

2019 Annual Meeting Program Chair: Brooke Ackerly, Vanderbilt University

Social Media Coordinator: M. Joel Voss, University of Toledo

Executive Council: Miriam deLoffre, Arcadia University; Lucas Swaine, Dartmouth University; Karen Zivi, Grand Valley State University

\section{Best Dissertation Award}

Recognizes the best dissertation written about the field of human rights in the previous year. Copies of the dissertation and a letter of support (less than 1,00o words) from the dissertation chair outlining the contributions of the dissertation to the field of human rights should be sent to the committee.

Nominations due: April 1, 2019

Award Committee: Alison Brysk, Chair, University of California, Santa Barbara 
Best Book Award

This competition is open to any book on human rights written by a political scientist and published in the previous two years. Please send one copy of the book to each member of the award committee.

Nominations due: April 1, 2019

Award Committee: Patrice McMahon, Chair, University of Nebraska-Lincoln; Bethany Barratt, Roosevelt University; George Andreopoulos, John Jay College, CUNY

\section{Best Paper Award}

This award recognizes the best paper presented on a Human Rights Section panel at the APSA Annual Meeting.

Nominations due: April 1, 2019

Award Committee: Richard Hiskes, Chair, Grand Valley State University

\section{SECTION 37: QUALITATIVE AND MULTI-METHOD RESEARCH \\ Formed: 2003 / Dues: \$9 for all members}

The goals of the section are to promote research and training focused on the several branches of methodology associated with the qualitative tradition; and to strive for an integrated understanding of these diverse methods and of their relationship to quantitative methods.

Website: http://www.maxwell.syr.edu/moynihan/cqrm/APSA_s Qualitative_and_Multi-Method_Research_Section/

Chair: TBA

Vice-Chair: TBA

\section{Secretary/ Treasurer: TBA}

Editors: Qualitative \& Multimethod Research: Tim Buthe, Duke University and Alan M. Jacobs, University of British Columbia

2019 Annual Meeting Program Chair: Jennifer Larson, Vanderbilt University

\section{Executive Council: TBA}

\section{Alexander L. George Article Award}

Honors Alexander George's contributions to the comparative case-study method, including his work linking that method to a systematic concern with research design, and his contribution of developing the idea and the practice of process-tracing. This award may be granted to a journal article or to a chapter in an edited volume that stands on its own as an article. The award will be given to an article or book chapter published in the calendar year prior to the year of the annual meeting at which the award is presented, with the date of publication being established by the journal issue for articles and the copyright date of the book for chapters. Articles or chapters published in 2018 will be eligible for the 2019 award.

\section{Nominations Due: TBA}

David Collier Mid-Career Achievement Award

Honors David Collier's contributions, through his research, graduate teaching, and institution-building, as a founder of the qualitative and multi-method research movement in contemporary political science. The award will be presented annually to a midcareer political scientist to recognize distinction in methodological publications, innovative application of qualitative and multimethod approaches in substantive research, and/or institutional contributions to this area of methodology.

\section{Nominations Due: TBA}

Giovanni Sartori Book Award

Honors Giovanni Sartori's work on qualitative methods and concept formation, and especially his contribution to helping scholars think about problems of context as they refine concepts and apply them to new spatial and temporal settings. The award is intended to encompass two types of contributions: new research on methodology per se, that is, studies that introduce specific methodological innovations or that synthesize and integrate methodological ideas in a way that is in itself a methodological contribution; and substantive work that is an exemplar for the application of qualitative methods. This award may be granted to a single- or coauthored book, or to an edited volume. The award will be given to works published in the calendar year prior to the year of the annual meeting at which the award is presented. The copyright date of a book will establish the relevant year. Hence, books with a 2018 copyright date will be eligible for the award presented at the 2019 APSA Annual Meeting.

\section{Nominations Due: TBA}

\section{Sage Paper Award}

Honors Sara and George McCune, who founded and sustained Sage Publications as a leading publisher of social science methodologyincluding, very centrally, qualitative methods. This award will be given to a paper presented at the previous annual meeting.

\section{Nominations Due: TBA}

\section{SECTION 38: SEXUALITY AND POLITICS}

Formed: 2007 / Dues: \$0 for students and \$10 for all other members The objective of the Sexuality and Politics Section is to bring together scholars working in a variety of areas within political science to facilitate the sharing of knowledge and to foster intellectual community and expertise within APSA.

Website: http://www.apsanet.org/section38

Chair: Patrick Egan, New York University

Secretary: Jo Wuest, University of Pennsylvania

Treasurer: Erin Mayo-Adam, Hunter College, CUNY

2019Annual Meeting Program Chair: Courtenay Daum, Colorado State University

Executive Council: R.G. Cravens, Bowling Green State University; Jennifer Raymond, Union Institute \& University; Megan Osterbur, New England College; Tiffany Willoughby-Herard, University of California Irvine

\section{Cynthia Weber Best Conference Paper Award}

The Best Conference Paper Award recognizes the best paper exploring sexuality and politics presented at the previous year's APSA Annual Meeting.

Nominations due: June 15, 2019

Award Committee: Tiffany Willoughby-Herard, Chair, University of California, Irvine; Inaki Sagarzazu, Texas Tech University; Anna L. Weissman, University of Florida; Zein Murib, Fordham University

\section{Kenneth Sherrill Best Dissertation Award}

The Best Dissertation Award recognizes the best dissertation on 
sexuality and politics completed and successfully defended in the previous two calendar years. The award is open to all scholarship that falls under the broad rubric of sexuality and politics, including studies concerning the regulation of sexuality, political responses to the regulation of sexuality, the uses of sexuality as a political construct, the intersections of sexuality with gender, race, and class, or LGBT politics and mobilizations.

Nominations due: June 15, 2019

Award Committee: Megan Osterbur, Chair, New England College; Edward Kammerer, Skidmore College; Ravi K. Perry, Virginia Commonwealth University

\section{SECTION 39: HEALTH POLITICS AND POLICY}

Formed: 2008 / Dues: \$0 for student members and $\$ 8$ for all other members

The Health Politics and Policy Section provides the ideal infrastructure in which members can more thoroughly, efficiently arm themselves with the additional expertise we need to explore health politics and policy questions. The section will define health politics and policy just as broadly as the phrase implies. Everything from the politics of Medicare Part D to the politics of women's health; everything from comparative politics of AIDS in Africa, Eastern Europe, and South Asia to the comparative state politics of Medicaid and SCHIP, everything from the ethics of end-oflife decisions to the regulation of stem cell research, everything from public budgeting and regulation to public health disaster preparedness fall with the scope of the section.

Website: http://www.apsanet.org/section39

Chair: Julia Lynch, University of Pennsylvania

Secretary: Jacqueline Cattopadhyay, University of North Carolina, Charlotte

Treasurer: John Hoornbeek, Kent State University

2019 Annual Meeting Program Chair: Miriam Laugesen, Columbia University

Executive Council: David Jones, Boston University; Scott Greer, University of Michigan; Jamila Michener, Cornell University; Philip Rocco, Marquette University

Leonard S. Robins Best Paper Award

The Leonard S. Robins Best Paper on Health Politics and Policy Award recognizes the best paper on any subject that fits under the rubric of health politics and policy presented at the previous annual meeting. All papers presented at panels sponsored or cosponsored by the Health Politics and Policy Section are eligible for consideration, and may be nominated by panel chairs, discussants, or others. All other substantively appropriate papers presented at panels organized by other sections, division, and related groups are also eligible, if the authors made an electronic version of their paper available to view online.

Nominations due: December 31, 2018

Award Committee: TBA

Outstanding Public Engagement

This award is offered to someone who has been working to improve health and the healthcare system by actively engaging in politics and policymaking.

Deadline: December 31, 2018
Award Committee: TBA

\section{SECTION 40: CANADIAN POLITICS}

Formed: 2009 / Dues: \$0 for students and \$8 for all other members

The purpose of this section is to promote the interest in Canadian politics, to provide a forum for the exchange of ideas and information related to Canadian politics, and to encourage the accumulation of knowledge about Canadian politics.

Website: www.canadianpoliticssection.org

Chair: TBA

Vice Chair: TBA

Secretary: TBA

Treasurer: TBA

2019 Annual Meeting Program Chair: Antoine Yoshinaka, University at Buffalo, SUNY

Executive Council: TBA

Mildred Schwartz Lifetime Achievement in the Study of Canadian Politics

The Schwartz Lifetime achievement award goes to scholars who have made significant contributions through their career to the study of Canadian politics, either through development of political analysis of Canada or through incorporating Canada as a significant case in comparative political analyses.

\section{Nominations due: TBA}

Award Committee: Daniel Cohn, Chair, York University; Mildred Schwartz, University of Illinois-Chicago; Patrick Fournier, Universite de Montreal; Mireille Lalancette, Universite du Quebec a Trois-Rivieres; Charles Doran

Seymour Martin Lipset Best Book Award

Books published by members of the PAS Canadian Politics Section dealing with Canadian politics, or incorporating Canada as a significant case in a comparative political analysis, that were published between 2012-2018 are eligible for consideration.

Nominations due: TBA

Award Committee: Keith Douglas Brownsey, Mount Royal University; Joanna Everitt, University of New Brunswick, Saint John; Christopher Alcantara, Western University; Greg Lyle, Innovative Research; Ken Cosgrove, Suffolk University

\section{SECTION 41: POLITICAL NETWORKS}

Formed: 2009 / Dues: \$0 for students and \$10 for other members

The purpose of the Political Networks Section is to promote intellectual exchange among scholars regarding the theoretical, methodological, and substantive aspects of political networks.

Website: http://www.polinetworks.org

Chair: Bruce Desmarais, Pennsylvania State University

Vice-Chair: Jennifer Larson, Vanderbilt University

Communications Director: Elizabeth Menninga, University of Iowa

Treasurer: Dino Christenson, Boston University

Membership Chair: Matthew Howell, Eastern Kentucky University 
Editor: Nodes $\mathcal{E}$ Edges: Elizabeth Menninga, University of Iowa

2019Annual Meeting Program Chair: Matthew Piertryka, Florida State University

Executive Council: Sharyar Minhas, Michigan State University; Rachel Blum, Miami University, Ohio; Jaime Settle, The College of William \& Mary

The Political Ties Award

This award is given on an annual basis to the best article published on political networks over the past two years.

Nominations due: April 1, 2019

Award Committee: TBA

\section{Best Book Award}

Awarded on a biennial basis to the best book published on political networks in a two-year period (current cycle includes a book published April 1, 2017 to March 31, 2019).

Nominations due: April 1, 2019

Award Committee: TBA

\section{Best Conference Paper Award}

This award is given annually to the best paper on political networks presented by a faculty member delivered at a political science conference in the previous year.

Nominations due: April 1, 2019

\section{Award Committee: TBA}

\section{John Sprague Award}

This award is given annually to the best paper on political networks presented by a graduate student delivered at a political science conference in the previous year. The award includes a cash award that comes from a supporting fund. The award is given based the contribution of the research to the study of political networks, broadly construed. The awardees' research can be substantive, theoretical, or methodological, so long as it meets the committee's definition of "excellence." Self-nominations are encouraged.

Nominations due: April 1, 2019

\section{Award Committee: TBA}

\section{Best Poster Award}

This award is given annually at the Political Networks Conference and is awarded to the best posters on political networks. Typically, two awards are given, but this is not a requirement. The award criteria are at the committee's discretion. Possibilities include giving one faculty award and one graduate award, giving one award for substantive contribution and one for a methodological contribution, or giving only one award. The program chairs for the conference appoint a committee who conduct evaluations at the conference. A cash award accompanies this prize.

\section{Nominations due: TBA}

\section{Award Committee: TBA}

\section{Career Achievement Award In Political Networks}

The Career Achievement Award is given to a scholar who has made major contributions that have had a long-term impact on the study of political networks.

Nominations due: April 30, 2019

Award Committee: TBA

\section{SECTION 42: EXPERIMENTAL RESEARCH}

Formed: 2010 / Dues: \$0 for student and professional members for online-only journal access; $\$ 18$ for student members for print and online journal access; $\$ 24$ for professional members for print and online journal access

The Experimental Research Section advances pedagogy, research, and scholarly contributions based on randomized or natural experiments. Recent years have seen a dramatic increase in the number of published articles in political science that use experiments. Experimentalists are exploring topics that would have been unimaginable only a few years ago. The rapid growth, development, and celebration of experimental methods in political science presents the opportunity to share a specific vocabulary and toolkit with researchers interested in experimental methods of all kinds. The section is devoted to helping scholars develop and hone these skills and to providing a forum where research based on these techniques can be shared and discussed.

Website: http://www.apsanet.org/section42

Chair: Rebecca Morton, New York University

Chair-Elect: Thad Dunning, University of California, Berkeley

Secretary: Anna Bassi, University of North Carolina at Chapel Hill

Treasurer: David Nickerson, Temple University

Editor: Journal of Experimental Political Science: Kevin Arceneaux, Temple University

2019 Annual Meeting Program Chairs: Dan Butler, University of California, San Diego and Brigitte Seim, University of North Carolina at Chapel Hill

Executive Council: Dustin Tingley, Harvard University; Claire Adida, University of California, San Diego; Adam Berinsky, Massachusetts Institute of Technology

\section{SECTION 43: MIGRATION AND CITIZENSHIP}

Formed: 2012 / Dues: \$5 for student members and \$10 for all other members

The purpose of this section is to bring together political scientists working on issues of migration and citizenship, promote teaching and research in the field, and encourage communication among political scientists and scholars of migration and citizenship in related disciplines, including policy and other professionals, domestically and internationally.

Website: https://connect.apsanet.org/s43/

Co-Chair: Sara Wallace Goodman, University of California, Irvine Co-Chair: Elizabeth Cohen, Syracuse University

Secretary: Abigail Williamson, Trinity College

Treasurer: Gerasimos Tsourapas, University of Birmingham

2019 Annual Meeting Program Chairs: Amy Liu, University of Texas, Austin and Rahsaan Maxwell, University of North Carolina at Chapel Hill

Executive Council: Justin Gest, George Mason University; Beyza Buyuker, University of Illinois at Chicago; Beth Whitaker, University of North Carolina at Charlotte; Osman Balkan, Swarthmore College; Loren Collingwood, University of California at Riverside; Rita Nassar, Indiana University 


\section{SECTION 44: AFRICAN POLITICS CONFERENCE GROUP}

Formed: 2013 / Dues: \$0 for students and \$10 for all other members

The African Politics and Conference Group Section promotes recognition of the theoretical and methodological contributions to the discipline of political scientists whose research and professional interests center largely or in part upon sub-Saharan Africa.

Website: https://connect.apsanet.org/s44/

Chair: Leonardo Arriola, University of California, Berkeley

Vice-Chair: Jessica Piombo, Naval Postgraduate School

Secretary: Jeffrey Paller, University of San Francisco

Treasurer: Claire Adida, University of California, San Diego

2019 Annual Meeting Program Chairs: Mai Hassan, University of Michigan, Ann Arbor and Graeme Blair, University of California, Los Angeles

\section{SECTION 45: CLASS AND INEQUALITY}

Formed: 2014 / Dues $\$ 5$ for students and \$10 for all other members

The Class and Inequality Section supports scholars of politics who study the political causes and consequences of economic inequality, social class stratification, and mobility and opportunity.

Website: https://connect.apsanet.org/s45/

Chair: Nicholas Carnes, Duke University

Secretary: Karen-Long-Jusko; Stanford University

Treasurer: Christopher Faricy, Syracuse University

2019 Annual Meeting Program Chairs: Nicholas Carnes, Duke University

Technology Officer: Cory Maks-Solomon, The George Washington University

SECTION 46: IDEAS, KNOWLEDGE, AND POLITICS

Formed: 2014 / Dues \$0 for students and \$10 for all other members

To understand political decisions and actions, it is necessary to study the sources and content of our political beliefs. To assess these decisions and actions, we need to study whether our political beliefs are accurate. Why do different people interpret the political world in different ways? How do they interpret either their own interests or the public interest; from what sources are these interpretations drawn; and how do these interpretations motivate political action? Given political actors' imperfect knowledge, how do they try to approximate full knowledge of the likely consequences of their actions, and how successful are these attempts? Under what conditions do political beliefs tend to be true? These questions have tended to be neglected within political science, with the result that our understandings of political processes are often incomplete. By addressing itself to the sources and the accuracy of our political beliefs, political epistemology seeks to fill a significant lacuna in political science and political theory.

Website: https://apsanet.org/section 46

Chair: Jeffrey Friedman, University of California, Berkeley

Communications Officer: Morgan Marietta, University of Massachusetts, Lowell

Secretary: Paul Gunn, University of London
Treasurer: Nick Clark, Susquehanna University

2019 Annual Meeting Program Chairs: Nick Clark, Susquehanna University and Jeffrey Friedman, University of California, Berkeley

Executive Council: Hélène Landemore, Yale University; Matthias Matthijs, Johns Hopkins University; Ben Miller, University of Illinois, Urbana-Champaign; Vivien Schmidt, Boston University; George Thomas, Claremont McKenna College

\section{Best APSA Paper by a Graduate Student or Post-Doc}

The Best Paper Award recognizes an annual meeting paper by a graduate student or post-doc, presented at an IKP panel, that best explored the role of ideas or knowledge in politics or government.

Nominations due: February 1, 2019

Award Committee: Paul Gunn, University of London; Hélène Landemore, Yale University

\section{Graduate Student/Post-Doc Travel Award}

The Travel Award is given to a graduate student or post-doc who submitted a proposal to present a paper at an Ideas, Knowledge, and Politics panel at the 2019 APSA Annual Meeting. Applications should include a description of the proposed paper in as much detail as possible.

Nominations due: January 15, 2019

Award Committee: Jeffrey Friedman, University of California, Berkeley; Paul Gunn, University of London; Matthias Matthijs, Johns Hopkins University

\section{Best Book Award}

The Best Book Award is given for the best recent work on empirical or normative aspects of the role of ideas or knowledge in politics or government. The awards committee is authorized to go back several years, at its discretion, and to make its own nominations as well as accepting nominations from others, including book authors and publishers. Nominated books published in 2018 or previously should be sent to committee members with a note or email message specifying that the book is being nominated. If only one copy of the book is available, please communicate this to the committee member to whom the book is sent. Authors are urged to follow up with publishers to be sure that books have been submitted on time.

Nominations due: February 1, 2019

Award Committee: Hélène Landemore, Yale University; Benjamin Miller, University of Illinois Urbana-Champaign; Jacob Roundtree, Harvard University

\section{SECTION 47: AMERICAN POLITICAL THOUGHT}

Formed: 2016 / Dues: \$25 for students with print and electronic journal access; \$20 for students for electronic-only journal access; \$35 for professional members with print and electronic journal access: $\$ 25$ for professional members with electronic-only journal access.

The purpose of this section is to facilitate and encourage a uniquely integrative approach to the study of politics that will put scholars of American politics, political theory, American political development, American history, philosophy, American literature, and other related fields in ongoing conversation with one another.

Website: http://apsanet.org/section 47

Chair: TBA

Vice Chair: TBA 
Secretary/Treasurer: TBA

Editor: American Political Thought: A Journal of Ideas, Institutions, and Culture: TBA

2019 Annual Meeting Program Chair: Daniel Klinghard, College of the Holy Cross

Executive Council: TBA

Best Book in American Political Thought

The Best Book in American Political Thought Award is chosen each year after the APSA Annual Meeting.

Nominations due: TBA

\section{Award Committee: TBA}

\section{Best Dissertation in American Political Thought}

The Best Dissertation in American Political Thought Award is chosen every two years. The executive council will select award recipients from the nominations provided by department chairs (one per department).

\section{Nominations due: TBA}

Award Committee: TBA

Best Article in American Political Thought

The Best Article in American Political Thought Award is chosen each year from among the articles published in American Political Thought the preceding year.

Nominations due: TBA

Award Committee: TBA

The Best Conference Paper in American Political Thought Award The Best Conference Paper in American Political Thought Award is chosen each year from nominations provided by panel chairs at the APSA Annual Meeting.

Nominations due: TBA

Award Committee: TBA

\section{SECTION 48: INTERNATIONAL COLLABORATION}

Formed: 2018 / Dues: \$10 for all members

The International Collaboration Section works to promote and disseminate research in and teaching of all facets of international collaboration and to encourage the interchange of ideas about international collaboration within the section, and with our disciplines, practitioners, and interested persons.

Chair: Leslie Johns, University of California, Los Angeles

Vice-Chair: Jana Von Stein, Australian National University

Secretary/Treasurer: Hyeran Jo, Texas A\&M University

2019Annual Meeting Program Chairs: Sarah Bush, Yale University and Erin Graham, Drexel University

\section{Best Article Award}

The Best Article Award is given for the best book on international collaboration published in 2018. Nominations, which must include a PDF of the article and publication information, should be emailed to the Section Chair at:1johns@polisci.ucla.edu.

Nominations due: February 15, 2019

Award Committee: Sarah Bauerle Danzman, Indiana University,
Bloomington; Marina E. Henke, Northwestern University; Lauren Prather, University of California, San Diego

\section{Best Book Award}

The Best Book Award is given for the best book on international collaboration published in 2018. Nominations, which must include a PDF of the full book manuscript, should be emailed to the Section Chair at:ljohns@polisci.ucla.edu.

Nominations due: February 15, 2019

Award Committee: Julia Gray, Chair, University of Pennsylvania; Michael Aklin, University of Pittsburgh; Elena McLean, SUNY University at Buffalo

\section{Best Dissertation Award}

The Best Dissertation Award is given for the best dissertation on international collaboration completed in 2018. Students may selfnominate their dissertations. Nominations, which must include a PDF of the filed version of the dissertation, should be emailed to the Section Chair at: ljohns@polisci.ucla.edu.

Nominations due: February 15, 2019

Award Committee: Susan Allen, University of Mississippi; Geoffrey Wallace, University of Washington, Seattle; Jeffrey Kucik, University of Arizona

Distinguished Mentor Award

The Distinguished Mentor Award is given for excellence in mentoring graduate students and junior faculty in the study of international collaboration. We particularly welcome nominations from groups of scholars who can provide a holistic assessment of their nominee's impact as a mentor. Nominations should be emailed to the Section Chair at:ljohns@polisci.ucla.edu

Nominations due: February 15, 2019

Award Committee: Leslie Johns, University of California, Los Angeles; Krzysztof Pelc, McGill University; Jana Von Stein, Australian National University

\section{SECTION 49: MENA POLITICS}

Formed: 2018 / Dues: \$10 for all members

The Middle East and North Africa (MENA) Politics Section was established to support, develop, and publish research on the politics of the MENA region utilizing interdisciplinary methodological, theoretical, and empirical tools. It seeks to fully integrate the rigorous study of the politics of the Middle East with the broader discipline of political science, to serve as an institutional home for the community of political scientists dedicated to the Middle East, and to fully integrate scholars from the MENA region and diverse scholars from the US into the global study of Middle East politics.

Chair: Marc Lynch, George Washington University

Vice-Chair: Lindsay Benstead, Portland State University

Treasurer: Steven Brooke, University of Louisville

Executive Council: Bassel Salloukh, Lebanese American University; Jillian Schwedler, Hunter College 